\title{
Longitudinal analysis of humoral immunity against SARS-CoV-2 Spike in convalescent individuals up to 8 months post-symptom onset
}

Sai Priya Anand ${ }^{1,2, *}$, Jérémie Prévost ${ }^{2,3, *}$, Manon Nayrac ${ }^{2,3, *}$, Guillaume Beaudoin-Bussières ${ }^{2,3, *}$, Mehdi Benlarbi ${ }^{2}$, Romain Gasser ${ }^{2,3}$, Nathalie Brassard ${ }^{2}$, Annemarie Laumaea ${ }^{2,3}$, Shang Yu Gong $^{1,2}$, Catherine Bourassa ${ }^{2}$, Elsa Brunet-Ratnasingham ${ }^{2,3}$, Halima Medjahed ${ }^{2}$, Gabrielle Gendron-Lepage ${ }^{2}$, Guillaume Goyette ${ }^{2}$, Laurie Gokool2 ${ }^{2}$, Chantal Morrisseau², Philippe Bégin ${ }^{2,5}$, Valérie Martel-Laferrière ${ }^{2,3}$, Cécile Tremblay 2,3 , Jonathan Richard ${ }^{2,3}$, Renée Bazin ${ }^{4}$, Ralf Duerr,\#, Daniel E. Kaufmann $2,7, \#$, and Andrés Finzi ${ }^{1,2,3, \#}$

${ }^{1}$ Department of Microbiology and Immunology, McGill University, Montreal, QC, Canada

${ }^{2}$ Centre de Recherche du CHUM, Montreal, QC, Canada

3Département de Microbiologie, Infectiologie et Immunologie, Université de Montréal, Montreal, QC,

Canada

${ }^{4}$ Héma-Québec, Affaires Médicales et Innovation, Quebec City, QC, Canada

${ }^{5} \mathrm{CHU}$ Ste-Justine, Montreal, QC, H3T 1C5, Canada

${ }^{6}$ Department of Pathology, New York University School of Medicine, New York, NY, USA

${ }^{7}$ Département de Médecine, Université de Montréal, Montreal, Quebec, Canada

${ }^{*}$ Contributed equally

\#Correspondence

Ralf Duerr - ralf.duerr@nyulangone.org

Daniel E. Kaufmann - daniel.kaufmann@umontreal.ca

Andrés Finzi - andres.finzi@umontreal.ca

Key Words: Coronavirus, COVID-19, SARS-CoV-2, Spike glycoproteins, RBD, Antibodies, Serology, Memory B cells, Humoral responses, ADCC, Neutralization, Convalescent plasma 


\section{Abstract}

Functional and lasting immune responses to the novel coronavirus (SARS-CoV-2) are currently under intense investigation as antibody titers in plasma have been shown to decline during convalescence. Since the absence of antibodies does not equate to absence of immune memory, we sought to determine the presence of SARS-CoV-2-specific memory B cells in COVID-19 convalescent patients. In this study, we report on the evolution of the overall humoral immune responses on 101 blood samples obtained from 32 COVID-19 convalescent patients between 16 and 233 days post-symptom onset. Our observations indicate that anti-Spike and anti-RBD IgM

37 in plasma decay rapidly, whereas the reduction of IgG is less prominent. Neutralizing activity in convalescent plasma declines rapidly compared to Fc-effector functions. Concomitantly, the frequencies of RBD-specific IgM+B cells wane significantly when compared to RBD-specific lgG+ B cells, which increase over time, and the number of IgG+ memory B cells which remain stable thereafter for up to 8 months after symptoms onset. With the recent approval of highly effective vaccines for COVID-19, data on the persistence of immune responses are of central importance. Even though overall circulating SARS-CoV-2 Spike-specific antibodies contract over time during convalescence, we demonstrate that RBD-specific B cells increase and persist up to 8 months post symptom onset. We also observe modest increases in RBD-specific lgG+ memory B cells and importantly, detectable IgG and sustained Fc-effector activity in plasma over the 8-month period. Our results add to the current understanding of immune memory following SARS-CoV-2 infection, which is critical for the prevention of secondary infections, vaccine efficacy and herd immunity against COVID-19. 


\section{Introduction}

51 Severe acute respiratory syndrome coronavirus-2 (SARS-CoV-2), the causative agent of the 52 ongoing Coronavirus disease 2019 (COVID-19) pandemic, is highly contagious and has infected 53 close to a 100 million people worldwide and caused over 2 million deaths since its discovery. The 54 dynamics and persistence of immune responses in individuals infected with SARS-CoV-2 is 55 currently under needful investigation. Several studies with acute and convalescent COVID-19 56 patients have showed prompt induction of B and T cell responses upon infection, along with the 57 detection of antigen-specific memory B and T cell responses several weeks into convalescence 58 (1-6). Additionally, antibodies induced upon infection have been shown to protect from SARS59 CoV-2 reinfection in animal models (7-9). Passive immunization using neutralizing monoclonal antibody treatments decreased viral loads in animal studies and in patients with COVID-19 (10,

61 11). The viral target of neutralizing antibodies is the highly immunogenic trimeric Spike (S) 62 glycoprotein, which facilitates SARS-CoV-2 entry into host cells via its receptor-binding domain $63(\mathrm{RBD})$ that interacts with angiotensin-converting enzyme 2 (ACE-2) $(12,13)$. disease symptoms (21).

In this study, we dissect multiple aspects of humoral immunity, including Fc-effector functions and 75 antigen-specific B cells, longitudinally for up to 8 months post symptom onset (PSO) in 32 
convalescent individuals. Our findings aid in the understanding of durability of COVID-19

77 immunity, which is important in the context of secondary infections, vaccine efficacy and herd

78 immunity.

\section{Results}

SARS-CoV-2 RBD-specific and Spike-specific antibody levels in convalescent plasma

\section{decrease up to 8 months post-symptom onset.}

83 To monitor the evolution of antibody responses longitudinally, we analyzed serological samples

84 from 32 convalescent individuals (Table 1) along with 10 pre-pandemic samples from uninfected

85 individuals as experimental controls. The average age of the donors was 47 years old (range: 20-

8665 years), and samples were from 17 males and 15 females. Convalescent patients were sampled

87 at four longitudinal time points between 16 and 233 days PSO: 6 weeks (16-95 days; median: 43 days), 11 weeks (48-127 days; median: 77 days), 21 weeks (116-171 days; median: 145 days), and 31 weeks (201-233 days; median: 218 days). Participants were tested positive for SARSCoV-2 infection by reverse transcription PCR (RT-PCR) on nasopharyngeal swab specimens. Convalescent participants were enrolled following two negative RT-PCR tests and a complete

We began by evaluating the presence of RBD-specific $\lg G$, $\lg M$, and $\lg A$ antibodies by using a previously published enzyme-linked immunosorbent assay (ELISA) against the SARS-CoV-2 RBD antigen (16). In agreement with recent reports showing the waning of antibody levels in

97 longitudinal convalescent plasma over time (14-17), we observed that total RBD-specific 98 immunoglobulin (lg) levels, comprising of $\lg G$, $\lg M$, and $\lg A$, gradually decreased between 6 and 9931 weeks after the onset of symptoms (Figure 1A). However, the percentage of convalescent 100 individuals presenting detectable RBD-specific lg levels remained stable, with a consistent 101 seropositivity rate above $90 \%$ throughout the sampling time frame. Notably, $100 \%$ of the donors 
102

103

104

105

106

107

108

109

110

111

112

113

114

115

116

117

118

119

120

121

122

123

124

125

126

127

still had detectable $\lg G$ at the last time point, while $\lg M$ and $\lg A$ diminished more rapidly, with $85 \%$ and $69 \%$ of the donors having undetectable $\lg \mathrm{M}$ and $\lg \mathrm{A}$ levels, respectively, 31 weeks PSO (Figure 1B-D; Figure S1A). Since the RBD ELISA is limited to detect antibodies targeting only one domain of the Spike, we developed a high-throughput cell-based ELISA methodology to screen for antibodies recognizing the native full-length $S$ protein on the cell surface. HOS cells stably expressing the SARS-CoV-2 S glycoproteins were incubated with plasma samples, followed by the addition of secondary antibodies recognizing $\lg \mathrm{G}$, $\lg \mathrm{M}$, and/or $\lg \mathrm{A}$. We observed that $100 \%$ of the donors still had detectable S-specific total Ig and IgG in their plasma at 31 weeks PSO whereas, only $38 \%$ and $54 \%$ of the plasma samples tested positive for the presence of Spikespecific $\lg \mathrm{M}$ and $\lg \mathrm{A}$, respectively (Figure $1 \mathrm{E}-\mathrm{H}$; Figure $\mathrm{S} 1 \mathrm{~B})$. We confirmed this observation using a recently characterized flow-cytometry based assay (22) determining antibody binding to the full-length S protein on the surface of 293T cells (Figure S2A). The data obtained with both the cell-based ELISA and flow-cytometry techniques correlated significantly $(r=0.8120$; $p<0.0001)$ (Figure S2B).

\section{Neutralizing and Fc-effector activities of antibodies present in convalescent plasma decrease at different rates over time.}

Recent studies have shown the importance of neutralizing antibodies in reducing viral load and preventing infection in animal models $(10,23,24)$. Neutralizing monoclonal antibody cocktails also reduced viral load in COVID-19 patients (11). Neutralizing activity is often considered as a determining factor in convalescent plasma therapy, although its relative importance compared to Fc-effector activity is still unknown (25-27). Thus, we measured the capacity of convalescent plasma to neutralize pseudoviral particles carrying the SARS-CoV-2 Spike protein over time. Neutralizing antibody titers $\left(\mathrm{ID}_{50}\right)$ were detected in $63 \%$ of the donors at 6 weeks PSO, while none of the uninfected controls had detectable neutralizing activity. Titers declined from 155.6 at 6 weeks to 60.0 at 31 weeks PSO, respectively, with $77 \%$ of donors having undetectable 
neutralization activity in their plasma at the last time point (Figure 2A). Since the depletion of IgM from plasma has been associated with loss of viral neutralization capacity $(28,29)$ and $\lg A$ has also been shown to dominate the early neutralizing response $(30,31)$, the sharp decline in neutralization activity seen in this study is corroborated by the striking decrease in anti-Spike and anti-RBD IgM and IgA levels (Figure 1B, D, F, H; Figure S1A, B).

Fc-mediated effector functions of antibodies can contribute to the efficacy of immune response against SARS-CoV-2. Recent studies have examined Fc-mediated effector functions of antibodies elicited upon SARS-CoV-2 infection $(19,32)$. Both the presence of IgG and their Fcmediated effector activities have been linked to reduced severity of disease (21). Herein, we assessed the ability of plasma from convalescent donors to trigger ADCC responses over time. We developed a new ADCC assay using a human T-lymphoid cell line resistant to NK cellmediated cell lysis (CEM.NKr) and stably expressing the full-length S protein on the cell surface as target cells. PBMCs from healthy individuals were used as effector cells. ADCC activity was measured by the loss of Spike-expressing GFP+ target cells (Figure S3). We observed that ADCC activity of convalescent plasma decreased gradually between 6 weeks and 31 weeks PSO (Figure 2B). However, this decline was modest when compared to the decrease in neutralization activity of plasma (Figure S1C) and $85 \%$ of the donors' plasma still elicited substantial ADCC activity at the latest study time point. The presence of Fc-mediated antibody effector functions up to 8 months PSO is corroborated with the presence of significant IgG levels.

\section{RBD-specific memory B cells develop and remain stable up to 8 months post-symptom onset.}

Recent studies on convalescent COVID-19 patients have indicated persistent antigen-specific memory $B$ cell responses despite waning antibody levels $(5,6)$. To monitor the circulating B cell compartment in our cohort of convalescent individuals, antigen-specific B cells were characterized 
by flow cytometry (identified as CD19+ CD20+). To identify distinct RBD-specific B cells, we used double discrimination with two recombinant RBD protein preparations labelled with fluorochromes Alexa-Fluor 594 and Alexa-Fluor 488, respectively. Detection of this double positive population was specific since it was not detected in PBMCs from uninfected individuals (Figure S4A, B). RBD-specific B cells were detected 6 weeks PSO with a modest increase in mean frequency up to 31 weeks PSO $(0.038 \%$ to $0.051 \%$ ) (Figure 3B). Total RBD-specific B cells were evaluated to distinguish surface $\lg$ isotypes and we observed $\lg \mathrm{G}_{+}, \lg \mathrm{M}_{+}$and $\lg \mathrm{A}+$ cells in $100 \%, 92 \%$ and $83 \%$ of donors at 6 weeks PSO, respectively. Strikingly, the frequency of RBD-specific IgM+ B cells decreased significantly, with $46 \%$ of the donors having undetectable lgM+ B cells 31 weeks PSO (Figure 3C; Figure S1D). Conversely, the frequency of RBD-specific IgG+ B cells significantly increased between 6 and 21 weeks PSO and remained stable up to 8 months PSO (Figure 3D); the detection of RBD-specific $\lg A+B$ cells also persisted in $77 \%$ of the donors tested (Figure 3E; Figure S1D). Furthermore, the total RBD-specific B cells were evaluated to distinguish memory and naïve B cells (identified by using CD27 and CD21 markers; Figure S4C, D). Importantly, total RBD-specific memory B cells were detected in $100 \%$ of the donors and the mean frequency remained stable between 6 and 31 weeks PSO (0.020\% to $0.026 \%)$, while RBDspecific naïve B cells were observed in lower proportions and modestly decreased over time

171 (Figure 3F, G). Interestingly, the proportion of donors positive for RBD-specific naïve B cells was 172 reduced by half between the first and last time point as also observed for RBD-specific $\lg M+B$ 173 cells which is consistent with the decline in IgM levels observed between these groups. IgG+ 174 RBD-specific memory B cells were detected in $100 \%$ of the donors and the frequency of this 175 population modestly increased up to 31 weeks PSO (Figure 3H). Meanwhile, the frequencies of $176 \lg A+$ RBD-specific memory B cells were low but stable over the 8-month period (Figure 3G, I). 
177 Evaluation of the relationship between different aspects of humoral immunity reveals the 178 importance of IgG responses.

179 To examine interrelations between serological, immunological, and functional parameters 180 assessed in this study, we performed comprehensive sets of correlation analyses. Firstly, at each 181 time point, the strongest immune response clusters were comprised of total $\lg$ and $\lg$ binding 182 levels and thus, increased ADCC activity (Figure 4A, left panel). In contrast, weaker immune 183 response clusters in plasma were formed by $\lg \mathrm{A}$ and $\lg \mathrm{M}$ levels and subsequently, neutralization 184 capacities. Overall, the responses decreased over the course of the 8-month period (Figure 4B). 185 The inverse was observed with antigen-specific B cell frequencies (Figure 4B). Apart from naïve 186 B cells and the IgM fraction thereof, total RBD-specific B cells increased over the course of 8 187 months. At each time point, total $\lg G+B$ cells and memory B cells $(\lg A+$ and $\lg G+)$ constituted 188 the most prominent responses (Figure 4A, right panel).

Additionally, at the earliest time point convalescent plasma was collected after symptom onset (6 weeks PSO), we observed a vast network of strong positive correlations among B cell 192 populations, antibody levels, and antibody-mediated functional parameters (Figure 5B). 193 Intriguingly, this was followed by a striking disconnect of associations between B cell frequencies 194 and serological parameters at 11, 21, and 31 weeks PSO (Figure 5C-E). This is caused by the 195 concomitant diminution of antibody levels, yet stabilization of antigen-specific B cells observed at 196 these time points, suggestive of decreased antibody production by B cells after resolution of 197 infection or the gradual replacement of Ig-secreting short-lived plasma cell by memory B cells. 198 When considering the collective datasets, prominent features were two subsequently dividing 199 positive correlation clusters, the first among total and IgG+ RBD-specific B cells and the second 200 among ADCC with total Ig and IgG binding responses. Furthermore, days PSO inversely 201 correlated with neutralization as well as $\lg M$ and $\lg A$-specific responses (Figure 5A and S5). 


\section{Discussion}

A better understanding of the type and longevity of immune responses following viral infections are critical to reveal immune mechanisms involved in protection from re-infection and protection by vaccination. Data regarding these important issues continues to be gathered for SARS-CoV2. In this study, we have contributed to the current understanding by reporting on the evolution of the overall humoral immune responses in 101 blood samples obtained from 32 COVID-19 convalescent patients between 16 and 233 days PSO. Overall, we observed that IgM levels and the neutralizing capacity of plasma decreases rapidly, whereas IgG and Fc-effector activity are more sustained (Figure 6). The antibody kinetics we observed herein are typical of those seen for other human coronavirus infections, with antibodies peaking 2-4 weeks PSO followed by a contraction phase (33). Furthermore, we show that COVID-19 patients generate RBD-specific memory B cells and IgG+ B memory cells that persist for over 8 months. Similarly, recent studies on the durability of SARS-CoV-2 immune responses have shown that although antibody levels decrease, Spike-specific IgG+ memory B cell responses are generated and maintained $(1,5,6)$. Additionally, studies demonstrated enhanced cellular immunity that protects non-human primates from SARS-CoV-2 reinfection in the context of waning neutralizing antibodies (8). Thus, the decline of antibody levels does not negate the protective potential because of the importance of cellular responses against SARS-CoV-2 infection. This understanding is corroborated with a recent risk assessment carried out in a cohort of 43,000 convalescent individuals demonstrating that immunity elicited upon natural SARS-CoV-2 infection protects against reinfection with an efficacy of $>90 \%$ for at least 7 months (34).

Fc-mediated effector activity of antibodies has been recently shown to correlate with reduced disease severity and mortality (21). Antibodies capable of mediating Fc-dependant functions, such as antibody-dependent phagocytosis and ADCC, have been isolated from convalescent donors (35). Importantly, Fc-mediated effector activity was shown to protect from SARS-CoV-2 
228 infection in adapted mice and hamster models $(9,19,32)$. Thus, our observations of the

229 persistence of ADCC responses in convalescent plasma up to 8 months PSO suggest that Fc-

230 mediated effector functions could play a vital role in protection from reinfection. Nevertheless, the

231 heterogeneity of immune responses between individuals is and will be an important factor when

232 evaluating the efficacy of immune responses upon re-exposure to SARS-CoV-2.

233

234 A recent study comparing humoral immunity generated by mRNA vaccinees (mRNA-1273 or

235 BNT162b2) and individuals recovered from natural infection observed similarities in antibody

236 binding titers and plasma neutralization capacity (36). Furthermore, this study also observed

237 similar frequencies of RBD-specific memory B cells between vaccinees and infected individuals.

238 Therefore, our results on the persistence of RBD-specific memory B cells up to 8 months after

239 natural infection is reassuring with regards to long-term vaccine efficacy. 


\section{Material and Methods}

\section{Ethics Statement}

242 All work was conducted in accordance with the Declaration of Helsinki in terms of informed

243 consent and approval by an appropriate institutional board. Convalescent plasmas were obtained

244 from donors who consented to participate in this research project at CHUM (19.381). The donors

245 met all donor eligibility criteria: previous confirmed COVID-19 infection and complete resolution 246 of symptoms for at least 14 days.

\section{Plasma and antibodies}

249 Plasma from SARS-CoV-2-infected and pre-pandemic uninfected donors were collected, heat250 inactivated for $1 \mathrm{~h}$ at $56^{\circ} \mathrm{C}$ and stored at $-80^{\circ} \mathrm{C}$ until ready to use in subsequent experiments. 251 Plasma from uninfected donors were used as negative controls and used to calculate the 252 seropositivity threshold in our ELISA, cell-based ELISA, and flow cytometry assays. The RBD253 specific monoclonal antibody CR3022 was used as a positive control in our ELISAs, cell-based 254 ELISAs, and flow cytometry assays and was previously described (14, 16, 22). Horseradish 255 peroxidase (HRP)-conjugated antibodies able to detect all $\lg$ isotypes (anti-human $\lg M+\lg G+\lg A$; 256 Jackson ImmunoResearch Laboratories, Inc.) or specific for the Fc region of human IgG 257 (Invitrogen), the Fc region of human IgM (Jackson ImmunoResearch Laboratories, inc.) or the Fc 258 region of human IgA (Jackson ImmunoResearch Laboratories, inc) were used as secondary 259 antibodies to detect antibody binding in ELISA and cell-based ELISA experiments. Alexa Fluor260 647-conjugated goat anti-human Abs able to detect all $\lg$ isotypes (anti-human $\lg M+\lg G+\lg A$; 261 Jackson ImmunoResearch Laboratories, Inc.) were used as secondary antibodies to detect 262 plasma binding in flow cytometry experiments.

\section{Cell lines}


293T human embryonic kidney cells (obtained from ATCC) were maintained at $37^{\circ} \mathrm{C}$ under $5 \%$ $\mathrm{CO}_{2}$ in Dulbecco's modified Eagle's medium (DMEM) (Wisent) containing $5 \%$ fetal bovine serum (VWR) and $100 \mu \mathrm{g} / \mathrm{ml}$ penicillin-streptomycin (Wisent). 293T-ACE2 and 293T-SARS-CoV-2 Spike cell lines were previously reported (16). For the generation of HOS and CEM.NKr CCR5+ cells stably expressing the SARS-CoV-2 Spike glycoproteins, transgenic lentiviruses were produced in 293T using a third-generation lentiviral vector system. Briefly, 293T cells were co-transfected with two packaging plasmids (pLP1 and pLP2), an envelope plasmid (pSVCMV-IN-VSV-G) and a lentiviral transfer plasmid coding for a GFP-tagged SARS-CoV-2 Spike (pLV-SARS-CoV-2 S CGFPSpark tag) (Sino Biological). Supernatant containing lentiviral particles was used to transduce HOS and CEM.NKr CCR5+ cells in presence of $5 \mu \mathrm{g} / \mathrm{mL}$ polybrene. The HOS and CEM.NKr CCR5+ cells stably expressing SARS-CoV-2 Spike (GFP+) were sorted by flow cytometry.

\section{Protein expression and purification}

FreeStyle 293F cells (Invitrogen) were grown in FreeStyle 293F medium (Invitrogen) to a density of $1 \times 10^{6} \mathrm{cells} / \mathrm{mL}$ at $37^{\circ} \mathrm{C}$ with $8 \% \mathrm{CO}_{2}$ with regular agitation (150 rpm). Cells were transfected with a plasmid coding for SARS-CoV-2 S RBD using ExpiFectamine 293 transfection reagent, as directed by the manufacturer (Invitrogen). One week later, cells were pelleted and discarded. Supernatants were filtered using a $0.22 \mu \mathrm{m}$ filter (Thermo Fisher Scientific). The recombinant RBD proteins were purified by nickel affinity columns, as directed by the manufacturer (Invitrogen). The RBD preparations were dialyzed against phosphate-buffered saline (PBS) and stored in aliquots at $-80^{\circ} \mathrm{C}$ until further use. To assess purity, recombinant proteins were loaded on SDS-PAGE gels and stained with Coomassie Blue.

\section{Enzyme-Linked Immunosorbent Assay (ELISA)}

The SARS-CoV-2 RBD ELISA assay used was recently described (16). Briefly, recombinant SARS-CoV-2 S RBD proteins $(2.5 \mu \mathrm{g} / \mathrm{ml})$, or bovine serum albumin (BSA) $(2.5 \mu \mathrm{g} / \mathrm{ml}$ ) as a 
291

292

293

negative control, were prepared in PBS and adsorbed to plates (MaxiSorp Nunc) overnight at $4^{\circ} \mathrm{C}$. Coated wells were subsequently blocked with blocking buffer (Tris-buffered saline [TBS] containing $0.1 \%$ Tween20 and $2 \%$ BSA) for $1 \mathrm{~h}$ at room temperature. Wells were then washed four times with washing buffer (Tris-buffered saline [TBS] containing $0.1 \%$ Tween20). CR3022 $\mathrm{mAb}(50 \mathrm{ng} / \mathrm{ml})$ or a $1 / 250$ dilution of plasma from SARS-CoV-2-infected or uninfected donors were prepared in a diluted solution of blocking buffer $(0.1 \% \mathrm{BSA})$ and incubated with the RBDcoated wells for 90 minutes at room temperature. Plates were washed four times with washing buffer followed by incubation with secondary Abs (diluted in blocking buffer,0.4\% BSA) for $1 \mathrm{~h}$ at room temperature, followed by four washes. HRP enzyme activity was determined after the addition of a 1:1 mix of Western Lightning oxidizing and luminol reagents (Perkin Elmer Life Sciences). Light emission was measured with a LB942 TriStar luminometer (Berthold Technologies). Signal obtained with BSA was subtracted for each plasma and was then normalized to the signal obtained with CR3022 mAb present in each plate. The seropositivity threshold was established using the following formula: mean of all COVID-19 negative plasma + (3 standard deviation of the mean of all COVID-19 negative plasma).

\section{Cell-Based ELISA}

Detection of the trimeric SARS-CoV-2 Spike at the surface of HOS cells was performed by cellbased enzyme-linked immunosorbent assay (ELISA). Briefly, parental HOS cells or HOS-Spike cells were seeded in 384 -well plates $\left(2.8 \times 10^{4}\right.$ cells per well) overnight. Cells were blocked with blocking buffer (washing buffer [1.8 $\mathrm{mM} \mathrm{CaCl}_{2}, 1 \mathrm{mM} \mathrm{MgCl}$, $25 \mathrm{mM}$ Tris (pH 7.5), and $140 \mathrm{mM}$ $\mathrm{NaCl}$ s supplemented with $10 \mathrm{mg} / \mathrm{mL}$ non-fat dry milk and $5 \mathrm{mM}$ Tris [pH 8.0]) for $30 \mathrm{~min}$. CR3022 $\mathrm{mAb}(1 \mu \mathrm{g} / \mathrm{ml})$ or plasma from SARS-CoV-2-infected or uninfected donors (at a dilution of $1 / 250$ ) were prepared in blocking buffer and incubated with the cells for $1 \mathrm{~h}$ at room temperature. Respective HRP-conjugated secondary antibodies were then incubated with the samples for 45 min at room temperature. For all conditions, cells were washed 6 times with blocking buffer and 
3176 times with washing buffer. HRP enzyme activity was determined after the addition of a 1:1 mix

318 of Western Lightning oxidizing and luminol reagents (PerkinElmer Life Sciences). Light emission

319 was measured with an LB 942 TriStar luminometer (Berthold Technologies). Signal obtained with

320 parental HOS was subtracted for each plasma and was then normalized to the signal obtained

321 with CR3022 mAb present in each plate. The seropositivity threshold was established using the

322 following formula: mean of all COVID-19 negative plasma + (3 standard deviation of the mean of

323 all COVID-19 negative plasma).

\section{Cell surface staining and flow cytometry analysis}

326 293T and 293T-Spike cells were mixed at a 1:1 ratio and stained with the anti-RBD CR3022 monoclonal Ab (5 $\mu \mathrm{g} / \mathrm{ml})$ or plasma (1:250 dilution). AlexaFluor-647-conjugated goat anti-human $\lg M+\lg G+\lg A$ Abs (1:800 dilution) were used as secondary antibodies. The percentage of transduced cells (GFP+ cells) was determined by gating the living cell population based on viability dye staining (Aqua Vivid, Invitrogen). Samples were acquired on a LSRII cytometer (BD Biosciences) and data analysis was performed using FlowJo v10.7.1 (Tree Star). The seropositivity threshold was established using the following formula: mean of all COVID-19 negative plasma + (3 standard deviation of the mean of all COVID-19 negative plasma).

\section{ADCC assay}

336 For evaluation of anti-SARS-CoV-2 antibody-dependent cellular cytotoxicity (ADCC), parental 337 CEM.NKr CCR5+ cells were mixed at a 1:1 ratio with CEM.NKr. Spike cells. These cells were 338 stained for viability (AquaVivid; Thermo Fisher Scientific, Waltham, MA, USA) and cellular dyes 339 (cell proliferation dye eFluor670; Thermo Fisher Scientific) and subsequently used as target cells.

340 Overnight rested PBMCs were stained with another cellular marker (cell proliferation dye 341 eFluor450; Thermo Fisher Scientific) and used as effector cells. Stained target and effector cells 342 were mixed at a ratio of 1:10 in 96-well V-bottom plates. Plasma from COVID+ or COVID- 
individuals (1/500 dilution) or monoclonal antibody CR3022 $(1 \mu \mathrm{g} / \mathrm{mL})$ were added to the appropriate wells. The plates were subsequently centrifuged for $1 \mathrm{~min}$ at $300 \mathrm{xg}$, and incubated at $37^{\circ} \mathrm{C}, 5 \% \mathrm{CO}_{2}$ for 5 hours before being fixed in a $2 \%$ PBS-formaldehyde solution. ADCC activity was calculated using the formula: [(\% of GFP+ cells in Targets plus Effectors)-(\% of GFP+ cells in Targets plus Effectors plus plasma/antibody)]/(\% of GFP + cells in Targets) $x 100$ by gating on transduced live target cells. All samples were acquired on an LSRII cytometer (BD Biosciences) and data analysis performed using FlowJo v10.7.1 (Tree Star). The specificity threshold was established using the following formula: mean of all COVID-19 negative plasma + ( 3 standard deviation of the mean of all COVID-19 negative plasma)

\section{Virus neutralization assay}

293T-ACE2 target cells were infected with single-round luciferase-expressing SARS-CoV-2 pseudoparticles in presence of convalescent plasma. Briefly, 293T cells were transfected by the calcium phosphate method with the lentiviral vector pNL4.3 R-E- Luc (NIH AIDS Reagent Program) and a plasmid encoding for SARSCoV-2 Spike at a ratio of 5:4. Two days posttransfection, cell supernatants were harvested and stored at $-80^{\circ} \mathrm{C}$ until use. $293 \mathrm{~T}$-ACE2 target cells were seeded at a density of $1 \times 10^{4}$ cells/well in 96-well luminometer-compatible tissue culture plates (Perkin Elmer) 24h before infection. Recombinant viruses in a final volume of $100 \mu \mathrm{L}$ were incubated with the indicated plasma dilutions $(1 / 50 ; 1 / 250 ; 1 / 1250 ; 1 / 6250 ; 1 / 31250)$ for $1 \mathrm{~h}$ at $37^{\circ} \mathrm{C}$ and were then added to the target cells followed by incubation for $48 \mathrm{~h}$ at $37^{\circ} \mathrm{C}$; cells were lysed by the addition of $30 \mu \mathrm{L}$ of passive lysis buffer (Promega) followed by one freeze-thaw cycle. An LB942 TriStar luminometer (Berthold Technologies) was used to measure the luciferase activity of each well after the addition of $100 \mu \mathrm{L}$ of luciferin buffer $\left(15 \mathrm{mM} \mathrm{MgSO}_{4}, 15 \mathrm{mM} \mathrm{KPO}_{4}\right.$ [pH 7.8], $1 \mathrm{mM} \mathrm{ATP}$, and $1 \mathrm{mM}$ dithiothreitol) and $50 \mu \mathrm{L}$ of $1 \mathrm{mM}$ d-luciferin potassium salt (Thermo Fisher Scientific). The neutralization half-maximal inhibitory dilution $\left(\mathrm{ID}_{50}\right)$ represents the plasma dilution to inhibit $50 \%$ of the infection of 293 T-ACE2 cells by SARS-CoV-2 pseudoviruses. 


\section{Detection of antigen-specific B cells}

371 To detect SARS-CoV-2-specific B cells, we conjugated recombinant RBD proteins with Alexa

372 Fluor 488 or Alexa Fluor 594 (Thermo Fisher Scientific) according to the manufacturer's protocol.

373 Approximately $10 \times 10^{6}$ frozen PBMC from 13 convalescent donors were prepared in Falcon®

$3745 \mathrm{ml}-$ round bottom polystyrene tubes at a final concentration of $14 \times 10^{6} \mathrm{cells} / \mathrm{mL}$ in RPMI 1640

375 medium (Gibco by Life Technologies, \#11875-093) supplemented with $10 \%$ of fetal bovine serum

376 (Seradigm, \#1500-500), Penicillin- Streptomycin (Gibco by Life Technologies, \#15140122) and

377 HEPES (Gibco by Life Technologies, \#15630-080). After a rest of $2 \mathrm{~h}$ at $37^{\circ} \mathrm{C}$ and $5 \% \mathrm{CO}_{2}, \mathrm{cells}$

378 were stained using Aquavivid viability marker (Gibco by Life Technologies) in DPBS (Gibco by

379 Life Technologies, \#14190-144) at $4^{\circ} \mathrm{C}$ for $20 \mathrm{~min}$. The detection of SARS-CoV-2-antigen specific

380 B cells was done by adding the RBD probes to the following antibody cocktail: IgM BUV737 (Clone

381 UCH-B1, \#748928), CD24 BUV805 (Clone ML5, \#742010), IgG BV421 (Clone G18-145,

382 \#562581), CD3 BV480 (Clone UCHT1, \#), CD56 BV480 (Clone NCAM16.2, \#566124), CD14

383 BV480 (Clone NCAM16.2, \#746304), CD16 BV480 (Clone 3G8, \#566108), CD20 BV711 (Clone

384 2H7, \#563126), CD21 BV786 (Clone B-LY4, \#740969), HLA DR BB700 (Clone G46-6, \#566480),

385 CD27 APC R700 (Clone M-T271, \#565116) all from BD Biosciences; CD19 BV650 (Clone 386 SJ25C1, \#363026) from Biolegend and IgA PE (Clone IS11-8E10 \#130-113-476) from Miltenyi.

387 Staining was performed at $4^{\circ} \mathrm{C}$ for $30 \mathrm{~min}$ and cells were fixed using $2 \%$ paraformaldehyde at $4^{\circ} \mathrm{C}$ 388 for 15min. Stained PBMC samples were acquired on Symphony cytometer (BD Biosciences) and 389 analyzed using FlowJo v10.7.1 (TreeStar). In each experiment, PBMC from unexposed donors 390 (total of $n=9$ ) were included to ensure consistent specificity of the assay.

\section{Statistical analyses}

393 Statistics were analyzed using GraphPad Prism version 9.0.0 (GraphPad, San Diego, CA). Every 394 dataset was tested for statistical normality and this information was used to apply the appropriate 
(parametric or nonparametric) statistical test. $\mathrm{P}$ values $<0.05$ were considered significant; significance values are indicated as $* p<0.05, * * p<0.01, * * * p<0.001, * * * * p<0.0001$. Multiplicity adjustments of $p$ values were performed with the Benjamini-Hochberg method in $R$ and R Studio $(37,38)$ using the data.table and tidyverse packages.

\section{Software scripts and visualization}

401 Normalized heatmaps were generated using the complexheatmap, tidyverse, and viridis packages in R and RStudio $(37,38)$. Normalizations were done per parameter. IDs were grouped and clustered separately according to time point. Correlograms were generated using the corrplot and RColorBrewer packages in program $\mathrm{R}$ and RStudio using hierarchical clustering according to the first principal component (FPC). Circular barplots were generated in R and RStudio using the tidyverse package with averaged, normalized data per parameter and time point. Edge bundling graphs were generated in undirected mode in R and RStudio using ggraph, igraph, tidyverse, and RColorBrewer packages. Edges are only shown if $p<0.05$, and nodes are sized according to the connecting edges' $r$ values. Nodes are color-coded according to groups of parameters. Area graphs were generated for the display of normalized time series. The plots were created in RawGraphs using DensityDesign interpolation and vertically un-centered values (39).

\section{Acknowledgements}

414 The authors are grateful to the convalescent plasma donors who participated in this study. The 415 authors thank the CRCHUM BSL3 and Flow Cytometry Platforms for technical assistance. We 416 thank Dr. Stefan Pöhlmann and Dr. Markus Hoffmann (Georg-August University, Germany) for 417 the plasmid coding for SARS-CoV-2 S glycoproteins and Dr. M. Gordon Joyce (U.S. MHRP) for 418 the monoclonal antibody CR3022. This work was supported by le Ministère de l'Économie et de 419 I'Innovation du Québec, Programme de soutien aux organismes de recherche et d'innovation to A.F., by the Fondation du CHUM and the Fondation du CHU Sainte-Justine. This work was also 
421 supported by Canada's COVID-19 Immunity Task Force (CITF), in collaboration with the

422 Canadian Institutes of Health Research (CIHR) (Grant VR2-173203), a ClHR foundation grant

423 \#352417 to A.F., by CIHR COVID-19 Rapid Research Funding to A.F., R.B. and P.B. and by an

424 Exceptional Fund COVID-19 from the Canada Foundation for Innovation (CFI) \#41027 to A.F.

425 and D.E.K. A.F. is the recipient of Canada Research Chair on Retroviral Entry no. RCHS0235

426 950-232424. V.M.L. and P.B. are supported by FRQS Junior 1 salary awards. D.E.K. is a FRQS

427 Merit Research Scholar. R.D. was supported by NIH grant R01 Al122953-05. S.P.A, J.P. and

428 G.B.B. are supported by CIHR fellowships. R.G. is supported by a MITACS Accélération

429 postdoctoral fellowship. The funders had no role in study design, data collection and analysis,

430 decision to publish, or preparation of the manuscript. We declare no competing interests. 
Figure 1. Decline of RBD- and Spike-specific antibodies in Iongitudinal convalescent plasma.

(A-D) Indirect ELISA was performed using recombinant SARS-CoV-2 RBD protein and incubation with COVID-19+ plasma samples recovered between 6 and 31 weeks post-symptom onset. Anti-

437 RBD antibody binding was detected using HRP-conjugated $(\mathbf{A})$ anti-human $\lg \mathrm{M}+\lg \mathrm{G}+\lg \mathrm{A}(\mathbf{B})$ anti-

438 human IgM , (C) anti-human IgG, or (D) anti-human IgA. Relative light unit (RLU) values obtained with BSA (negative control) were subtracted and further normalized to the signal obtained with the anti-RBD CR3022 mAb present in each plate. (E-H) Cell-based ELISA was performed using HOS cells expressing full-length SARS-CoV-2 Spike and incubation with COVID-19+ plasma samples recovered between 6 and 31 weeks post-symptom onset. Anti-Spike antibody binding was detected using HRP-conjugated (E) anti-human $\operatorname{lgM}+\lg \mathrm{G}+\lg \mathrm{A}(\mathbf{F})$ anti-human $\operatorname{lgM},(\mathbf{G})$ anti-

444 human IgG, or $(\mathbf{H})$ anti-human IgA. RLU values obtained with parental HOS (negative control) were subtracted and further normalized to the signal obtained with the CR3022 mAb present in each plate. (Left panels) Each curve represents the normalized RLUs obtained with the plasma

447 of one donor at every donation as a function of the days after symptom onset. (Right panels)

448 Plasma samples were grouped in different timepoints post-symptom onset $(6,11,21$ and 31 449 weeks). Undetectable measures are represented as white symbols, and limits of detection are 450 plotted. Error bars indicate means \pm SEM. Statistical significance was tested using repeated 451 measures one-way ANOVA with a Holm-Sidak post-test $\left({ }^{*} \mathrm{P}<0.05 ;{ }^{* *} \mathrm{P}<0.01\right.$; ${ }^{* * *} \mathrm{P}<0.001$; $452 * * * * P<0.0001)$ 
(A) Pseudoviral particles coding for the luciferase reporter gene and bearing the SARS-CoV-2 S glycoproteins were used to infect 293T-ACE2 cells. Neutralizing activity was measured by incubating pseudoviruses with serial dilutions of COVID-19+ plasma samples recovered between

4596 and 31 weeks post-symptom onset at $37^{\circ} \mathrm{C}$ for $1 \mathrm{~h}$ prior to infection of 293T-ACE2 cells. 460 Neutralization half maximal inhibitory serum dilution $\left(\right.$ ID $\left._{50}\right)$ values were determined using a normalized non-linear regression using GraphPad Prism software. (B) CEM.NKr parental cells were mixed at a 1:1 ratio with CEM.NKr-Spike cells and were used as target cells. PBMCs from uninfected donors were used as effector cells in a FACS-based ADCC assay. The graphs shown represent the percentages of ADCC obtained in the presence of COVID-19+ plasma samples recovered between 6 and 31 weeks post-symptom onset. (Left panels) Each curve represents (A) the neutralization $\mathrm{ID}_{50}$ or $(\mathbf{B})$ the percentages of $A D C C$ obtained with the plasma of one donor at every donation as a function of the days after symptom onset. (Right panels) Plasma samples were grouped in different timepoints post-symptom onset $(6,11,21$ and 31 weeks). Undetectable ANOVA with a Holm-Sidak post-test $\left({ }^{*} \mathrm{P}<0.05 ;{ }^{* *} \mathrm{P}<0.01 ;{ }^{* * *} \mathrm{P}<0.001 ;{ }^{* * * *} \mathrm{P}<0.0001\right)$.

474 onset.

475 (A) Flow cytometry plots of staining with fluorescent SARS-CoV-2 RBD probes on CD19+ CD20+ 476 HLA-DR+ B cells. Samples from one representative convalescent donor are shown for 4 different 477 timepoints post-symptom onset $(6,11,21$ and 31 weeks). All percentages shown represent the 478 frequency of RBD-specific B cells on the total CD19+ CD20+ B cell population. (B-G) 479 Characterization of RBD-specific B cells was performed on longitudinal PBMC samples obtained 480 from COVID-19+ convalescent individuals between 6 and 31 weeks post-symptom onset. (B) 481 Total RBD-specific B cells were segregated by subsets based on cell surface expression of (C) 
$482 \lg M,(\mathbf{D}) \lg \mathrm{G}$ or $(\mathbf{E}) \lg \mathrm{A}$ BCR isotypes. Frequency of $(\mathbf{F})$ total memory, $(\mathbf{G})$ naïve, $(\mathbf{H}) \lg \mathrm{G}+$ memory

483 and (I) $\lg A+$ memory B cells were determined based on CD21 and CD27 expression. (Left

484 panels) Each curve represents the frequency of a B cell subset on the total B cell population 485 obtained with PBMCs from one donor at every donation as a function of the days after symptom 486 onset. (Right panels) PBMC samples were grouped in different timepoints post-symptom onset $487(6,11,21$ and 31 weeks). Error bars indicate means \pm SEM. Statistical significance was tested 488 using repeated measures one-way ANOVA with a Holm-Sidak post-test $\left({ }^{*} \mathrm{P}<0.05\right.$; ns, 489 nonsignificant)

Figure 4. Longitudinal patterns of B cell levels and humoral immune responses.

(A) (Left panel) Heatmap of humoral immune responses normalized per parameter. Columns represent immune response parameters clustered based on similarity and grouped according to the provided color code. Rows represent IDs grouped according to study time point. IDs are clustered according to their immune response profiles within each time point. (Right panel) Heatmap of B cell levels with similar display as in (left panel). (B) Circular bar plots represent averaged values of parameters at each time point.

Figure 5. Longitudinal plasticity and separation of B cell and humoral correlation clusters.

500 Edge bundling correlation plots where red and blue edges represent positive and negative correlations between connected parameters, respectively. Only significant correlations $(p<0.05)$ are displayed. Nodes are color-coded based on the grouping of parameters according to the legend at the bottom. Node size corresponds to the degree of relatedness of correlations. Edge bundling plots are shown for correlation analyses using all data points (A) and datasets of individual time points, i.e., at 6 weeks (B), 11 weeks (C), 21 weeks (D), and 31 weeks (E). 
Figure 6. Evolution of humoral immune responses and B cell levels in SARS-CoV-2 convalescent individuals over time.

Area plots showing time series of selected, humoral immune responses and B cell levels by interpolation of normalized, averaged values per parameter and time point. The timeline is shown at the bottom with ticks indicating study time points. convalescence phase.

(A) The graph shown represents the mean values for anti-RBD ELISA (from Figure 1A-D) at graph shown represents the mean values for anti-Spike cell-based ELISA (from Figure 1E-H) at different timepoints $(6,11,21$ and 31 weeks) normalized to the 6 weeks timepoint. (C) The graph shown represents the mean values for neutralization and ADCC responses (from Figure

2) at different timepoints $(6,11,21$ and 31 weeks) normalized to the 6 weeks timepoint. (D) The

521 graph shown represents the mean values for RBD-specific B cell frequencies (from Figure 3B-

522 E) at different timepoints $(6,11,21$ and 31 weeks) normalized to the 6 weeks timepoint.

Supplemental Figure 2. Detection of antibodies against SARS-CoV-2 Spike by flow cytometry correlates with anti-Spike detection by cell-based ELISA.

526 (A) Cell-surface staining of 293T cells stably expressing full-length SARS-CoV-2 Spike using 527 samples from COVID-19+ convalescent donors at different times after symptoms onset $(6,11,21$ 528 and 31 weeks). The graphs shown represent the median fluorescence intensities (MFI) obtained on the GFP+ population. MFIs values obtained with parental 293T (GFP-) were subtracted. (Left panel) Each curve represents the MFIs obtained with the plasma of one donor at every donation as a function of the days after symptom onset. (Right panel) Plasma samples were grouped in 
532 different timepoints post-symptom onset $(6,11,21$ and 31 weeks). Undetectable measures are

533 represented as white symbols, and limits of detection are plotted. Error bars indicate means \pm

534 SEM. (B) The levels of anti-Spike total Ig quantified by flow cytometry were correlated with the

535 level of anti-Spike total Ig quantified by cell-based ELISA. Statistical significance was tested using

536 (A) a repeated measures one-way ANOVA with a Holm-Sidak post-test or (B) a Spearman

537 correlation rank test $\left({ }^{*} \mathrm{P}<0.05 ;{ }^{* *} \mathrm{P}<0.01 ;{ }^{* \star * *} \mathrm{P}<0.0001\right)$.

\section{Supplemental Figure 3. Gating strategy for ADCC measurements.}

540 Target cells were identified according to cell morphology by light-scatter parameters (first column)

541 and excluding doublets cells (second column). Cells were then gated on eFluor670+ cells

542 (excluding the effector cells labeled with efluor450; third column). Finally, the percentage of

543 GFP+ target cells was used to calculate ADCC activity (last column). Examples of gating using

544 (A) parental CEM.NKr or (B) a 1:1 ratio mix of CEM.NKr and CEM.NKr.Spike as target cells in absence or (C) in presence of effector cells. (D) ADCC assay performed in the presence of plasma samples from one representative convalescent donor at 4 different timepoints post-symptom onset $(6,11,21$ and 31 weeks).

Supplemental Figure 4. Gating strategy for SARS-CoV-2-specific B cell characterization.

(A-B) Representative flow cytometry gates to identify RBD-specific B cells from PBMCs of (A) uninfected and (B) convalescent donor. (C-D) Flow cytometry gates used to differentiate RBD-

552 specific B cell subtypes using isotypic and maturation cell surface markers on samples obtained

553 (C) 6 weeks and (D) 31 weeks post-symptom onset. After identification of isotypic subtypes, RBD-

554 specific naïve and memory B cells were characterized based on surface expression of CD21 and

555 CD27. The different RBD-specific B cell subpopulations were superimposed on total

556 CD19+/CD20+/HLA-DR+ B cells (grey). Legend: IgM+ and naïve IgM+ B cells, blue; IgG+ and

557 memory lgG+ B cells, red; $\lg A+$ and memory $\lg A+B$ cells, orange. 
559 Supplemental Figure 5. Correlations between serological, immunological and 560 demographic determinants.

561 Correlograms were generated by plotting together all serological, immunological and 562 demographic data obtained from convalescent patients. Circles are color-coded and sized 563 according to the magnitude of the correlation coefficient $(r)$. Red circles represent positive 564 correlations between two variables and blue circles represent negative correlations. Asterisks 565 indicate statistically significant correlations $\left({ }^{*} P<0.05,{ }^{* *} P<0.01,{ }^{* *} P<0.005\right)$. Correlation 566 analysis was done using Spearman correlation rank tests. Parameters are clustered hierarchically 567 according to the first principal component (FPC). Black surrounding boxes indicate adjusted p568 values < 0.05 using Benjamini-Hochberg multiplicity correction. Legend: Cb-ELISA = cell-based

569 ELISA, Neut $=$ Neutralization, mem $=$ memory, PSO $=$ post-symptom onset, Sex $=$ Female. 


\section{References}

571 1. Dan JM, Mateus J, Kato Y, Hastie KM, Yu ED, Faliti CE, Grifoni A, Ramirez SI, Haupt S,

572

573

574

575

576

577

578

579

580

581

582

583

584

585

586

587

588

589

590

591

592

593

594

595

596

597

598

599

600

601

602

603

604

605

606

607

608

609

610

611

612

613

614

615

616

617

618

619

Frazier A, Nakao C, Rayaprolu V, Rawlings SA, Peters B, Krammer F, Simon V, Saphire EO, Smith DM, Weiskopf D, Sette A, Crotty S. 2021. Immunological memory to SARSCoV-2 assessed for up to 8 months after infection. Science doi:10.1126/science.abf4063.

2. Grifoni A, Weiskopf D, Ramirez SI, Mateus J, Dan JM, Moderbacher CR, Rawlings SA, Sutherland A, Premkumar L, Jadi RS, Marrama D, de Silva AM, Frazier A, Carlin AF, Greenbaum JA, Peters B, Krammer F, Smith DM, Crotty S, Sette A. 2020. Targets of T Cell Responses to SARS-CoV-2 Coronavirus in Humans with COVID-19 Disease and Unexposed Individuals. Cell 181:1489-1501 e15.

3. Rydyznski Moderbacher C, Ramirez SI, Dan JM, Grifoni A, Hastie KM, Weiskopf D, Belanger S, Abbott RK, Kim C, Choi J, Kato Y, Crotty EG, Kim C, Rawlings SA, Mateus J, Tse LPV, Frazier A, Baric R, Peters B, Greenbaum J, Ollmann Saphire E, Smith DM, Sette A, Crotty S. 2020. Antigen-Specific Adaptive Immunity to SARS-CoV-2 in Acute COVID19 and Associations with Age and Disease Severity. Cell 183:996-1012 e19.

4. Hartley GE, Edwards ESJ, Aui PM, Varese N, Stojanovic S, McMahon J, Peleg AY, Boo I, Drummer HE, Hogarth PM, O'Hehir RE, van Zelm MC. 2020. Rapid generation of durable B cell memory to SARS-CoV-2 spike and nucleocapsid proteins in COVID-19 and convalescence. Sci Immunol 5.

5. Wheatley AK, Juno JA, Wang JJ, Selva KJ, Reynaldi A, Tan H-X, Lee WS, Wragg KM, Kelly HG, Esterbauer R, Davis SK, Kent HE, Mordant FL, Schlub TE, Gordon DL, Khoury DS, Subbarao K, Cromer D, Gordon TP, Chung AW, Davenport MP, Kent SJ. 2020. Evolution of immunity to SARS-CoV-2. doi:10.1101/2020.09.09.20191205 \%J medRxiv:2020.09.09.20191205.

6. Gaebler C, Wang Z, Lorenzi JCC, Muecksch F, Finkin S, Tokuyama M, Cho A, Jankovic M, Schaefer-Babajew D, Oliveira TY, Cipolla M, Viant C, Barnes CO, Bram Y, Breton G, Hägglöf T, Mendoza P, Hurley A, Turroja M, Gordon K, Millard KG, Ramos V, Schmidt F, Weisblum Y, Jha D, Tankelevich M, Martinez-Delgado G, Yee J, Patel R, Dizon J, UnsonO'Brien C, Shimeliovich I, Robbiani DF, Zhao Z, Gazumyan A, Schwartz RE, Hatziioannou T, Bjorkman PJ, Mehandru S, Bieniasz PD, Caskey M, Nussenzweig MC. 2021. Evolution of antibody immunity to SARS-CoV-2. Nature doi:10.1038/s41586-021-03207-w.

7. Chandrashekar A, Liu J, Martinot AJ, McMahan K, Mercado NB, Peter L, Tostanoski LH, Yu J, Maliga Z, Nekorchuk M, Busman-Sahay K, Terry M, Wrijil LM, Ducat S, Martinez DR, Atyeo C, Fischinger S, Burke JS, Slein MD, Pessaint L, Van Ry A, Greenhouse J, Taylor T, Blade K, Cook A, Finneyfrock B, Brown R, Teow E, Velasco J, Zahn R, Wegmann F, Abbink P, Bondzie EA, Dagotto G, Gebre MS, He X, Jacob-Dolan C, Kordana N, Li Z, Lifton MA, Mahrokhian SH, Maxfield LF, Nityanandam R, Nkolola JP, Schmidt AG, Miller $A D$, Baric RS, Alter G, Sorger PK, Estes JD, et al. 2020. SARS-CoV-2 infection protects against rechallenge in rhesus macaques. Science 369:812-817.

8. McMahan K, Yu J, Mercado NB, Loos C, Tostanoski LH, Chandrashekar A, Liu J, Peter L, Atyeo C, Zhu A, Bondzie EA, Dagotto G, Gebre MS, Jacob-Dolan C, Li Z, Nampanya F, Patel S, Pessaint L, Van Ry A, Blade K, Yalley-Ogunro J, Cabus M, Brown R, Cook A, Teow E, Andersen H, Lewis MG, Lauffenburger DA, Alter G, Barouch DH. 2020. Correlates of protection against SARS-CoV-2 in rhesus macaques. Nature doi:10.1038/s41586-020-03041-6.

9. Tortorici MA, Beltramello M, Lempp FA, Pinto D, Dang HV, Rosen LE, McCallum M, Bowen J, Minola A, Jaconi S, Zatta F, De Marco A, Guarino B, Bianchi S, Lauron EJ, Tucker H, Zhou J, Peter A, Havenar-Daughton C, Wojcechowskyj JA, Case JB, Chen RE, Kaiser H, Montiel-Ruiz M, Meury M, Czudnochowski N, Spreafico R, Dillen J, Ng C, Sprugasci N, Culap K, Benigni F, Abdelnabi R, Foo SC, Schmid MA, Cameroni E, Riva A, 
Gabrieli A, Galli M, Pizzuto MS, Neyts J, Diamond MS, Virgin HW, Snell G, Corti D, Fink K, Veesler D. 2020. Ultrapotent human antibodies protect against SARS-CoV-2 challenge via multiple mechanisms. Science doi:10.1126/science.abe3354.

10. Baum A, Ajithdoss D, Copin R, Zhou A, Lanza K, Negron N, Ni M, Wei Y, Mohammadi K, Musser B, Atwal GS, Oyejide A, Goez-Gazi Y, Dutton J, Clemmons E, Staples HM, Bartley C, Klaffke B, Alfson K, Gazi M, Gonzalez O, Dick E, Jr., Carrion R, Jr., Pessaint L, Porto M, Cook A, Brown R, Ali V, Greenhouse J, Taylor T, Andersen H, Lewis MG, Stahl N, Murphy AJ, Yancopoulos GD, Kyratsous CA. 2020. REGN-COV2 antibodies prevent and treat SARS-CoV-2 infection in rhesus macaques and hamsters. Science 370:1110-1115.

11. Weinreich DM, Sivapalasingam S, Norton T, Ali S, Gao H, Bhore R, Musser BJ, Soo Y, Rofail D, Im J, Perry C, Pan C, Hosain R, Mahmood A, Davis JD, Turner KC, Hooper AT, Hamilton JD, Baum A, Kyratsous CA, Kim Y, Cook A, Kampman W, Kohli A, Sachdeva Y, Graber X, Kowal B, DiCioccio T, StahI N, Lipsich L, Braunstein N, Herman G, Yancopoulos GD, Trial I. 2020. REGN-COV2, a Neutralizing Antibody Cocktail, in Outpatients with Covid-19. N Engl J Med doi:10.1056/NEJMoa2035002.

12. Walls AC, Park YJ, Tortorici MA, Wall A, McGuire AT, Veesler D. 2020. Structure, Function, and Antigenicity of the SARS-CoV-2 Spike Glycoprotein. Cell 181:281-292 e6.

13. Hoffmann M, Kleine-Weber H, Schroeder S, Kruger N, Herrler T, Erichsen S, Schiergens TS, Herrler G, Wu NH, Nitsche A, Muller MA, Drosten C, Pohlmann S. 2020. SARS-CoV2 Cell Entry Depends on ACE2 and TMPRSS2 and Is Blocked by a Clinically Proven Protease Inhibitor. Cell 181:271-280 e8.

14. Beaudoin-Bussières G, Laumaea A, Anand SP, Prévost J, Gasser R, Goyette G, Medjahed H, Perreault J, Tremblay T, Lewin A, Gokool L, Morrisseau C, Bégin P, Tremblay C, Martel-Laferrière V, Kaufmann DE, Richard J, Bazin R, Finzi A. 2020. Decline of Humoral Responses against SARS-CoV-2 Spike in Convalescent Individuals. mBio 11:e02590-20.

15. Perreault J, Tremblay T, Fournier MJ, Drouin M, Beaudoin-Bussières G, Prévost J, Lewin A, Bégin P, Finzi A, Bazin R. 2020. Waning of SARS-CoV-2 RBD antibodies in longitudinal convalescent plasma samples within four months after symptom onset. Blood doi:10.1182/blood.2020008367.

16. Prévost J, Gasser R, Beaudoin-Bussières G, Richard J, Duerr R, Laumaea A, Anand SP, Goyette G, Benlarbi M, Ding S, Medjahed H, Lewin A, Perreault J, Tremblay T, GendronLepage G, Gauthier N, Carrier M, Marcoux D, Piché A, Lavoie M, Benoit A, Loungnarath V, Brochu G, Haddad E, Stacey HD, Miller MS, Desforges M, Talbot PJ, Gould Maule GT, Côté M, Therrien C, Serhir B, Bazin R, Roger M, Finzi A. 2020. Cross-sectional evaluation of humoral responses against SARS-CoV-2 Spike. Cell Rep Med doi:10.1016/j.xcrm.2020.100126:100126.

17. Robbiani DF, Gaebler C, Muecksch F, Lorenzi JCC, Wang Z, Cho A, Agudelo M, Barnes CO, Gazumyan A, Finkin S, Hagglof T, Oliveira TY, Viant C, Hurley A, Hoffmann HH, Millard KG, Kost RG, Cipolla M, Gordon K, Bianchini F, Chen ST, Ramos V, Patel R, Dizon J, Shimeliovich I, Mendoza P, Hartweger H, Nogueira L, Pack M, Horowitz J, Schmidt F, Weisblum Y, Michailidis E, Ashbrook AW, Waltari E, Pak JE, Huey-Tubman KE, Koranda N, Hoffman PR, West AP, Jr., Rice CM, Hatziioannou T, Bjorkman PJ, Bieniasz PD, Caskey M, Nussenzweig MC. 2020. Convergent antibody responses to SARS-CoV-2 in convalescent individuals. Nature 584:437-442.

18. Ibarrondo FJ, Fulcher JA, Goodman-Meza D, Elliott J, Hofmann C, Hausner MA, Ferbas KG, Tobin NH, Aldrovandi GM, Yang OO. 2020. Rapid Decay of Anti-SARS-CoV-2 Antibodies in Persons with Mild Covid-19. N Engl J Med 383:1085-1087.

19. Chan CEZ, Seah SGK, Chye DH, Massey S, Torres M, Lim APC, Wong SKK, Neo JJY, Wong PS, Lim JH, Loh GSL, Wang DL, Boyd-Kirkup JD, Guan S, Thakkar D, Teo GH, Purushotorman K, Hutchinson PE, Young BE, Lye DC, Low JG, MacAry PA, Hentze H, 
Prativadibhayankara VS, Ethirajulu K, O'Connell D, Comer J, Tseng C-TK, Barrett ADT, Ingram PJ, Brasel T, Hanson BJ. 2020. The Fc-mediated effector functions of a potent SARS-CoV-2 neutralizing antibody, SC31, isolated from an early convalescent COVID-19 patient, are essential for the optimal therapeutic efficacy of the antibody. doi:10.1101/2020.10.26.355107 \%J bioRxiv:2020.10.26.355107.

20. Dufloo J, Grzelak L, Staropoli I, Madec Y, Tondeur L, Anna F, Pelleau S, Wiedemann A, Planchais C, Buchrieser J, Robinot R, Ungeheuer M-N, Mouquet $\mathrm{H}$, Charneau P, White M, Lévy Y, Hoen B, Fontanet A, Schwartz O, Bruel T. 2020. Asymptomatic and symptomatic SARS-CoV-2 infections elicit polyfunctional antibodies. doi:10.1101/2020.11.12.20230508 \%J medRxiv:2020.11.12.20230508.

21. Zohar T, Loos C, Fischinger S, Atyeo C, Wang C, Slein MD, Burke J, Yu J, Feldman J, Hauser BM, Caradonna T, Schmidt AG, Cai Y, Streeck H, Ryan ET, Barouch DH, Charles RC, Lauffenburger DA, Alter G. 2020. Compromised Humoral Functional Evolution Tracks with SARS-CoV-2 Mortality. Cell 183:1508-1519 e12.

22. Anand SP, Prévost J, Richard J, Perreault J, Tremblay T, Drouin M, Fournier M-J, Lewin A, Bazin R, Finzi A. 2020. High-throughput detection of antibodies targeting the SARSCoV-2 Spike in longitudinal convalescent plasma samples. doi:10.1101/2020.10.20.346783 \%J bioRxiv:2020.10.20.346783.

23. Hansen J, Baum A, Pascal KE, Russo V, Giordano S, Wloga E, Fulton BO, Yan Y, Koon K, Patel K, Chung KM, Hermann A, Ullman E, Cruz J, Rafique A, Huang T, Fairhurst J, Libertiny C, Malbec M, Lee WY, Welsh R, Farr G, Pennington S, Deshpande D, Cheng J, Watty A, Bouffard P, Babb R, Levenkova N, Chen C, Zhang B, Romero Hernandez A, Saotome K, Zhou Y, Franklin M, Sivapalasingam S, Lye DC, Weston S, Logue J, Haupt R, Frieman M, Chen G, Olson W, Murphy AJ, Stahl N, Yancopoulos GD, Kyratsous CA. 2020. Studies in humanized mice and convalescent humans yield a SARS-CoV-2 antibody cocktail. Science 369:1010-1014.

24. Rogers TF, Zhao F, Huang D, Beutler N, Burns A, He WT, Limbo O, Smith C, Song G, Woehl J, Yang L, Abbott RK, Callaghan S, Garcia E, Hurtado J, Parren M, Peng L, Ramirez S, Ricketts J, Ricciardi MJ, Rawlings SA, Wu NC, Yuan M, Smith DM, Nemazee D, Teijaro JR, Voss JE, Wilson IA, Andrabi R, Briney B, Landais E, Sok D, Jardine JG, Burton DR. 2020. Isolation of potent SARS-CoV-2 neutralizing antibodies and protection from disease in a small animal model. Science 369:956-963.

25. Rojas M, Rodriguez Y, Monsalve DM, Acosta-Ampudia Y, Camacho B, Gallo JE, RojasVillarraga A, Ramirez-Santana C, Diaz-Coronado JC, Manrique R, Mantilla RD, Shoenfeld Y, Anaya JM. 2020. Convalescent plasma in Covid-19: Possible mechanisms of action. Autoimmun Rev 19:102554.

26. Li L, Zhang W, Hu Y, Tong X, Zheng S, Yang J, Kong Y, Ren L, Wei Q, Mei H, Hu C, Tao C, Yang R, Wang J, Yu Y, Guo Y, Wu X, Xu Z, Zeng L, Xiong N, Chen L, Wang J, Man N, Liu Y, Xu H, Deng E, Zhang X, Li C, Wang C, Su S, Zhang L, Wang J, Wu Y, Liu Z. 2020. Effect of Convalescent Plasma Therapy on Time to Clinical Improvement in Patients With Severe and Life-threatening COVID-19: A Randomized Clinical Trial. JAMA 324:460-470.

27. Devasenapathy N, Ye Z, Loeb M, Fang F, Najafabadi BT, Xiao Y, Couban R, Begin P, Guyatt G. 2020. Efficacy and safety of convalescent plasma for severe COVID-19 based on evidence in other severe respiratory viral infections: a systematic review and metaanalysis. CMAJ 192:E745-E755.

28. Gasser R, Cloutier M, Prévost J, Fink C, Ducas É, Ding S, Dussault N, Landry P, Tremblay $T$, Laforce-Lavoie A, Lewin A, Beaudoin-Bussières G, Laumaea A, Medjahed $H$, Larochelle C, Richard J, Dekaban GA, Dikeakos JD, Bazin R, Finzi A. 2020. Major role of $\operatorname{lgM}$ in the neutralizing activity of convalescent plasma against SARS-CoV-2. doi:10.1101/2020.10.09.333278 \%J bioRxiv:2020.10.09.333278. 
29. Klingler J, Weiss S, Itri V, Liu X, Oguntuyo KY, Stevens C, Ikegame S, Hung CT, Enyindah-Asonye G, Amanat F, Baine I, Arinsburg S, Bandres JC, Kojic EM, Stoever J, Jurczyszak D, Bermudez-Gonzalez M, Nadas A, Liu S, Lee B, Zolla-Pazner S, Hioe CE. 2020. Role of IgM and IgA Antibodies in the Neutralization of SARS-CoV-2. medRxiv doi:10.1101/2020.08.18.20177303.

30. Sterlin D, Mathian A, Miyara M, Mohr A, Anna F, Claer L, Quentric P, Fadlallah J, Devilliers $H$, Ghillani P, Gunn C, Hockett R, Mudumba S, Guihot A, Luyt CE, Mayaux J, Beurton A, Fourati S, Bruel T, Schwartz O, Lacorte JM, Yssel H, Parizot C, Dorgham K, Charneau P, Amoura Z, Gorochov G. 2020. IgA dominates the early neutralizing antibody response to SARS-CoV-2. Sci Transl Med doi:10.1126/scitranslmed.abd2223.

31. Wang Z, Lorenzi JCC, Muecksch F, Finkin S, Viant C, Gaebler C, Cipolla M, Hoffmann $\mathrm{HH}$, Oliveira TY, Oren DA, Ramos V, Nogueira L, Michailidis E, Robbiani DF, Gazumyan A, Rice CM, Hatziioannou T, Bieniasz PD, Caskey M, Nussenzweig MC. 2020. Enhanced SARS-CoV-2 neutralization by dimeric IgA. Sci Transl Med doi:10.1126/scitransImed.abf1555.

32. Schäfer A, Muecksch F, Lorenzi JCC, Leist SR, Cipolla M, Bournazos S, Schmidt F, Maison RM, Gazumyan A, Martinez DR, Baric RS, Robbiani DF, Hatziioannou T, Ravetch JV, Bieniasz PD, Bowen RA, Nussenzweig MC, Sheahan TP. 2020. Antibody potency, effector function, and combinations in protection and therapy for SARS-CoV-2 infection in vivo. Journal of Experimental Medicine 218.

33. Huang AT, Garcia-Carreras B, Hitchings MDT, Yang B, Katzelnick LC, Rattigan SM, Borgert BA, Moreno CA, Solomon BD, Trimmer-Smith L, Etienne V, Rodriguez-Barraquer I, Lessler J, Salje H, Burke DS, Wesolowski A, Cummings DAT. 2020. A systematic review of antibody mediated immunity to coronaviruses: kinetics, correlates of protection, and association with severity. Nat Commun 11:4704.

34. Abu-Raddad LJ, Chemaitelly $H$, Coyle P, Malek JA, Ahmed AA, Mohamoud YA, Younuskunju S, Ayoub HH, Al Kanaani Z, Al Kuwari E, Butt AA, Jeremijenko A, Kaleeckal AH, Latif AN, Shaik RM, Abdul Rahim HF, Nasrallah GK, Yassine HM, Al Kuwari MG, Al Romaihi HE, Al-Thani MH, Khal AA, Bertollini R. 2021. SARS-CoV-2 reinfection in a cohort of 43,000 antibody-positive individuals followed for up to 35 weeks. doi:10.1101/2021.01.15.21249731 \%J medRxiv:2021.01.15.21249731.

35. Natarajan H, Crowley AR, Butler SE, Xu S, Weiner JA, Bloch EM, Littlefield K, WielandAlter W, Connor RI, Wright PF, Benner SE, Bonny TS, Laeyendecker O, Sullivan DJ, Shoham S, Quinn T, Larman HB, Casadevall A, Pekosz A, Redd A, Tobian AA, Ackerman ME. 2020. SARS-CoV-2 antibody signatures robustly predict diverse antiviral functions relevant for convalescent plasma therapy. medRxiv doi:10.1101/2020.09.16.20196154.

36. Wang Z, Schmidt F, Weisblum Y, Muecksch F, Barnes CO, Finkin S, Schaefer-Babajew D, Cipolla M, Gaebler C, Lieberman JA, Yang Z, Abernathy ME, Huey-Tubman KE, Hurley A, Turroja M, West KA, Gordon K, Millard KG, Ramos V, Silva JD, Xu J, Colbert RA, Patel R, Dizon JP, Unson-O'Brien C, Shimeliovich I, Gazumyan A, Caskey M, Bjorkman PJ, Casellas R, Hatziioannou T, Bieniasz PD, Nussenzweig MC. 2021. mRNA vaccine-elicited antibodies to SARS-CoV-2 and circulating variants. doi:10.1101/2021.01.15.426911\%J bioRxiv:2021.01.15.426911.

37. R Studio Team. 2015. RStudio: Integrated Development for R. , RStudio Inc., http://www.rstudio.com/.

38. $\mathrm{R}$ Development Core Team. 2013. R: A language and environment for statistical computing R Foundation for Statistical Computing, Vienna, Austria.

39. Mauri M, Elli T, Caviglia G, Uboldi G, Azzi M. 2017. RAWGraphs: A Visualisation Platform to Create Open Outputs, abstr Proceedings of the 12th Biannual Conference on Italian SIGCHI Chapter, Cagliari, Italy, Association for Computing Machinery, 
Table 1. Longitudinal SARS-CoV-2 convalescent cohort

\begin{tabular}{|c|c|c|c|c|c|}
\hline \multirow[b]{2}{*}{ Group } & \multirow[b]{2}{*}{$\mathbf{n}$} & \multirow[b]{2}{*}{$\begin{array}{c}\text { Days after onset of symptoms } \\
\text { (median; day range) }\end{array}$} & \multirow[b]{2}{*}{$\begin{array}{c}\text { Age } \\
\text { (median; age range) } \\
\end{array}$} & \multicolumn{2}{|c|}{ Sex } \\
\hline & & & & Male (n) & Female (n) \\
\hline 6 weeks & 32 & $\begin{array}{c}43 \\
(16-95)\end{array}$ & $\begin{array}{c}47 \\
(20-65)\end{array}$ & 17 & 15 \\
\hline 11 weeks & 28 & $\begin{array}{c}77 \\
(48-127)\end{array}$ & $\begin{array}{c}47 \\
(20-65)\end{array}$ & 16 & 12 \\
\hline 21 weeks & 28 & $\begin{array}{c}145 \\
(116-171)\end{array}$ & $\begin{array}{c}48 \\
(20-65)\end{array}$ & 16 & 12 \\
\hline 31 weeks & 13 & $\begin{array}{c}218 \\
(201-233)\end{array}$ & $\begin{array}{c}46 \\
(20-65)\end{array}$ & 9 & 4 \\
\hline
\end{tabular}




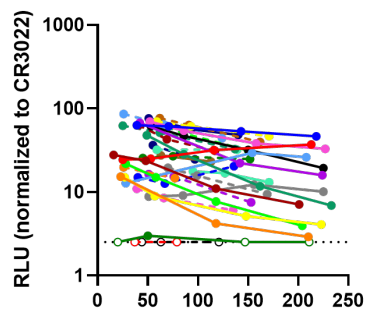

Days post symptom onset

anti-RBD IgG

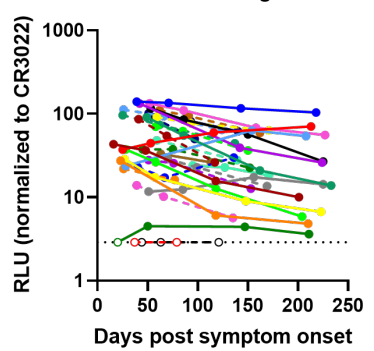

E

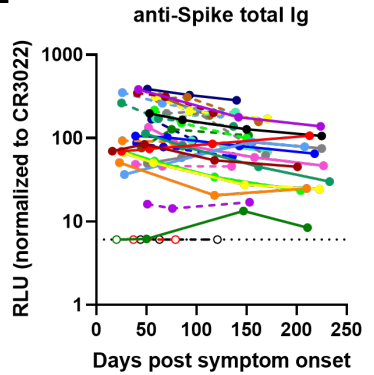

G

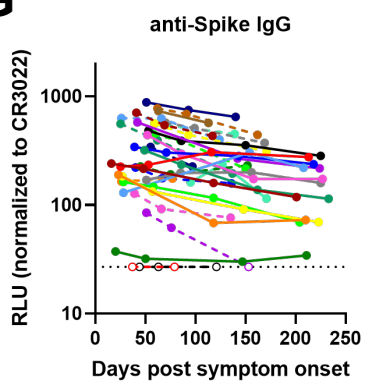

$\begin{array}{rrrrr}\text { Seropositivity (\%): } & \mathbf{9 1 \%} & \mathbf{9 3 \%} & 93 \% & 92 \% \\ \text { Mean: } & \mathbf{3 6 . 4} & \mathbf{2 9 . 6} & 23.2 & 16.6\end{array}$

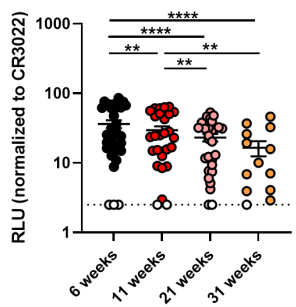

anti-RBD IgG

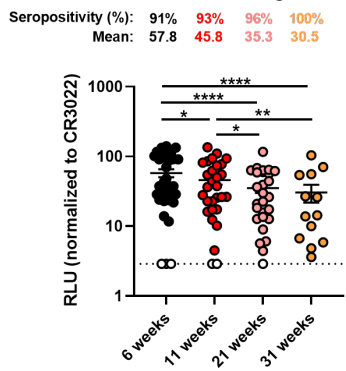

anti-Spike total Ig
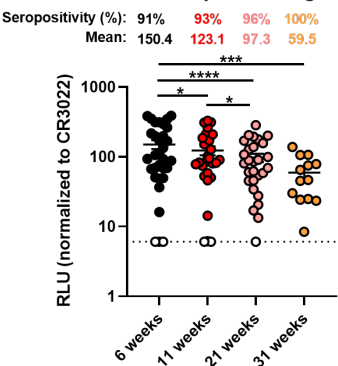

anti-Spike IgG

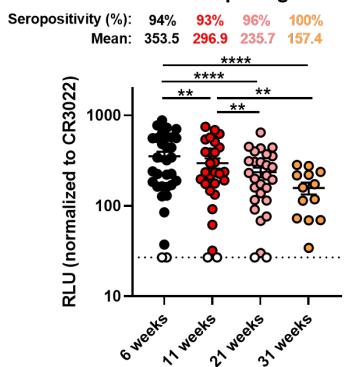

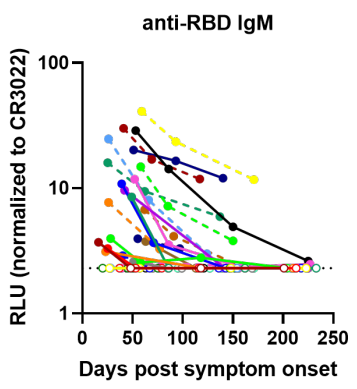

anti-RBD IgA

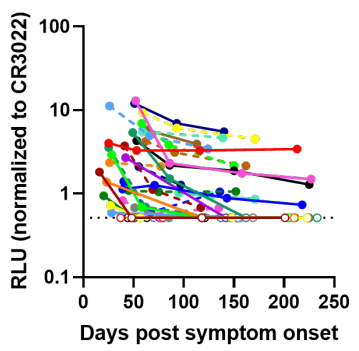

anti-Spike IgM

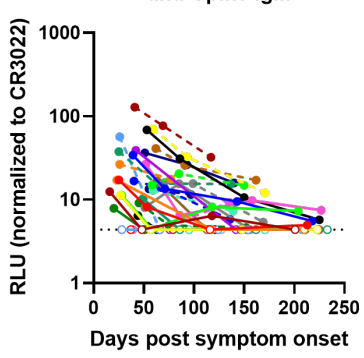

H

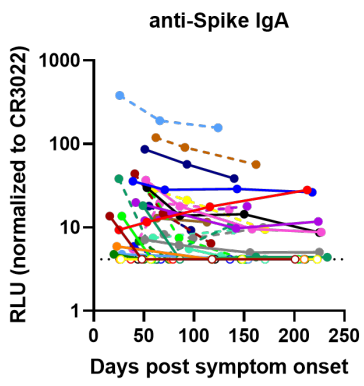

anti-RBD IgM

Seropositivity (\%): $\quad \mathbf{6 9} \% \quad \mathbf{5 0} \% \quad 36 \% \quad 15 \%$

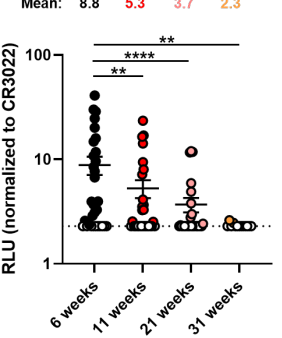

anti-RBD IgA
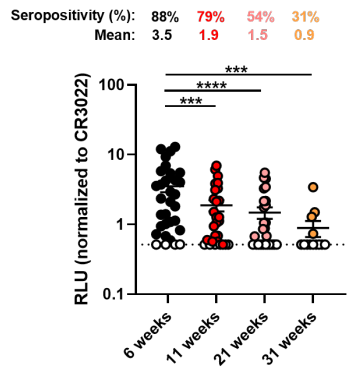

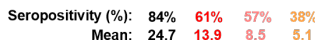

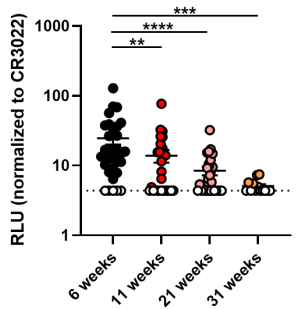

anti-Spike IgA

Seropositivity (\%): $\quad \mathbf{8 8} \% \quad 61 \% \quad 61 \% \quad 54 \%$ $\begin{array}{lllll}\text { Mean: } & 32.0 & 20.4 & 16.7 & 9.1\end{array}$

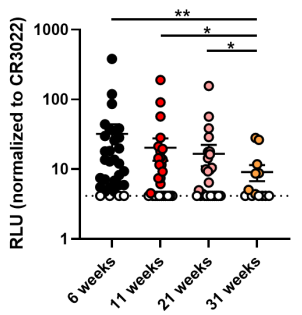

Figure 1. Decline of RBD- and Spike-specific antibodies in longitudinal convalescent plasma.

(A-D) Indirect ELISA was performed using recombinant SARS-CoV-2 RBD protein and incubation with COVID-19+ plasma samples recovered between 6 and 31 weeks post-symptom onset. Anti-RBD antibody binding was detected using HRP-conjugated (A) anti-human $\lg M+\lg G+\lg A(B)$ anti-human $\lg M,(C)$ anti-human $\lg G$, or (D) anti-human $\lg A$. Relative light unit (RLU) values obtained with $B S A$ (negative control) were subtracted and further normalized to the signal obtained with the anti-RBD CR3022 mAb present in each plate. (E-H) Cell-based ELISA was performed using HOS cells expressing full-length SARS-CoV-2 Spike and incubation with COVID-19+ plasma samples recovered between 6 and 31 weeks post-symptom onset. Anti-Spike antibody binding was detected using HRP-conjugated (E) anti-human $\lg M+\lg G+\lg A(F)$ anti-human $\lg M,(G)$ anti-human $\lg G$, or $(H)$ anti-human IgA. RLU values obtained with parental HOS (negative control) were subtracted and further normalized to the signal obtained with the CR3022 mAb present in each plate. (Left panels) Each curve represents the normalized RLUs obtained with the plasma of one donor at every donation as a function of the days after symptom onset. (Right panels) Plasma samples were grouped in different timepoints post-symptom onset (6,11, 21 and 31 weeks). Undetectable measures are represented as white symbols, and limits of detection are plotted. Error bars indicate means \pm SEM. Statistical significance was tested using repeated measures one-way ANOVA with a Holm-Sidak post-test $\left({ }^{*} \mathrm{P}<0.05 ;{ }^{* *} \mathrm{P}<0.01 ;{ }^{* * *} \mathrm{P}<0.001 ;{ }^{* * * *} \mathrm{P}<0.0001\right)$. 

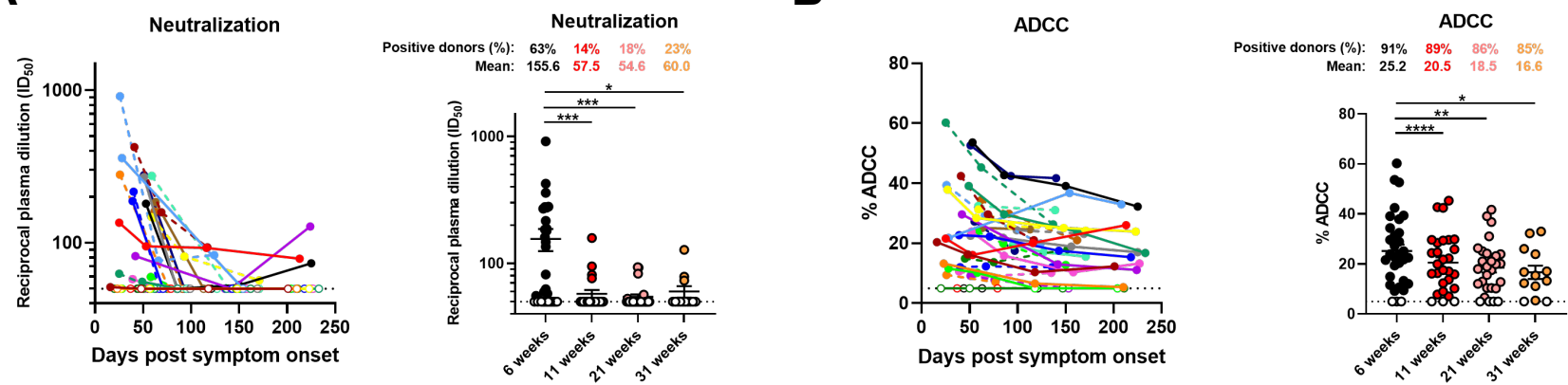

Figure 2. Neutralization and Fc-effector function activities in convalescent plasma decrease over time.

(A) Pseudoviral particles coding for the luciferase reporter gene and bearing the SARS-CoV-2 S glycoproteins were used to infect 293T-ACE2 cells. Neutralizing activity was measured by incubating pseudoviruses with serial dilutions of COVID-19+ plasma samples recovered between 6 and 31 weeks post-symptom onset at $37^{\circ} \mathrm{C}$ for $1 \mathrm{~h}$ prior to infection of 293T-ACE2 cells. Neutralization half maximal inhibitory serum dilution (ID50) values were determined using a normalized non-linear regression using GraphPad Prism software. (B) CEM.NKr parental cells were mixed at a 1:1 ratio with CEM.NKr-Spike cells and were used as target cells. PBMCs from uninfected donors were used as effector cells in a FACS-based ADCC assay. The graphs shown represent the percentages of ADCC obtained in the presence of COVID-19+ plasma samples recovered between 6 and 31 weeks post-symptom onset. (Left panels) Each curve represents (A) the neutralization ID50 or (B) the percentages of ADCC obtained with the plasma of one donor at every donation as a function of the days after symptom onset. (Right panels) Plasma samples were grouped in different timepoints post-symptom onset $(6,11,21$ and 31 weeks). Undetectable measures are represented as white symbols, and limits of detection are plotted. Error bars indicate means \pm SEM. Statistical significance was tested using repeated measures one-way ANOVA with a Holm-Sidak post-test $\left({ }^{*} \mathrm{P}<0.05\right.$; ${ }^{* *} \mathrm{P}<0.01$; ${ }^{* * *} \mathrm{P}<0.001$; $\left.{ }^{* * * *} \mathrm{P}<0.0001\right)$. 
A

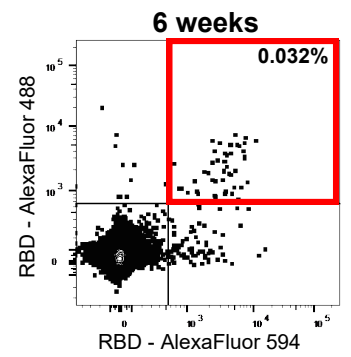

B

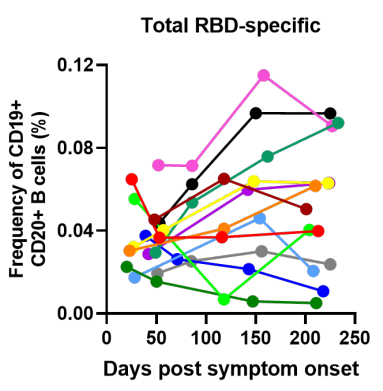

D

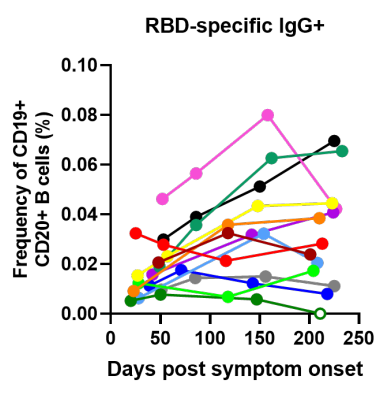

$\mathbf{F}$

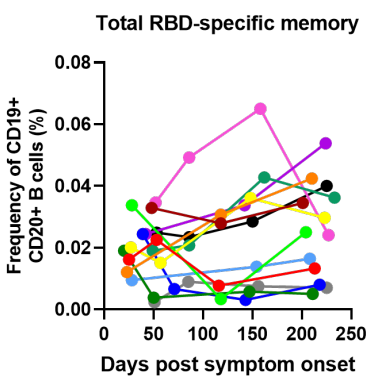

H

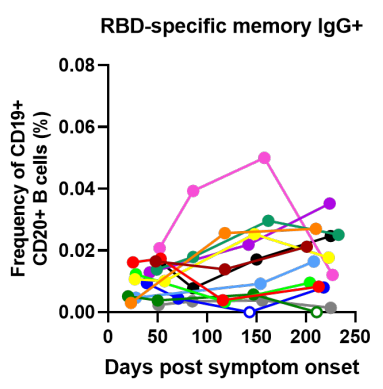

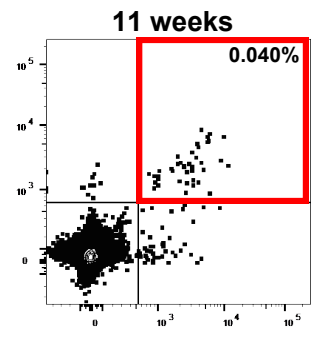

21 weeks
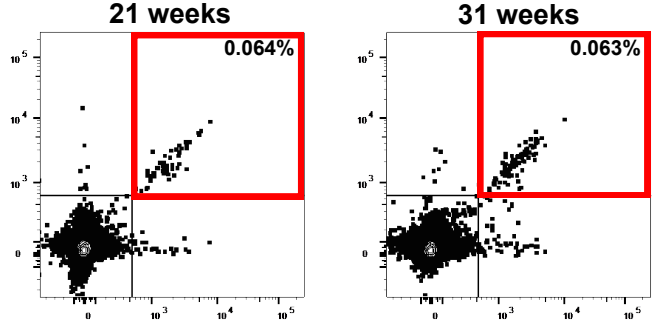

Total RBD-specific Positive donors: $\quad 100 \% \quad 100 \% \quad 100 \% \quad 100 \%$ $\begin{array}{lllll}\text { Mean frequency: } & \mathbf{0 . 0 3 8} & 0.042 & 0.051 & 0.051\end{array}$

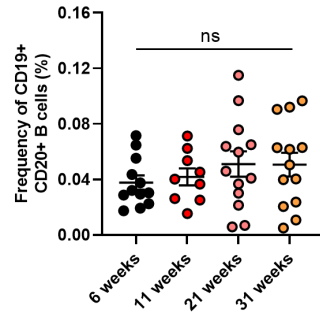

RBD-specific lgG+

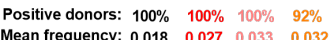

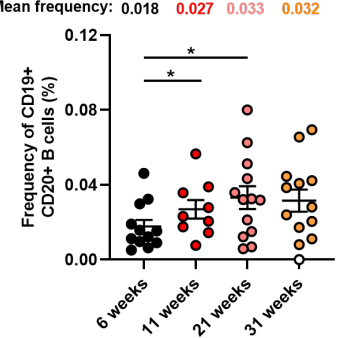

Total RBD-specific memory Positive donors: $100 \% \quad 100 \% \quad 100 \% \quad 100 \%$ Mean frequency: $\mathbf{0 . 0 2 0} \quad 0.020 \quad 0.024 \quad 0.026$

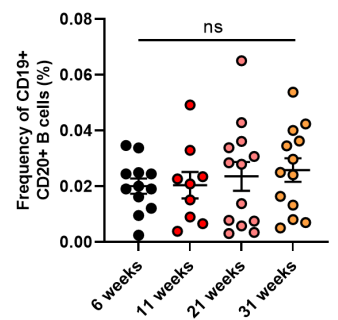

RBD-specific memory lgG+ Positive donors: $100 \% \quad 100 \% \quad 92 \% \quad 92 \%$ $\begin{array}{lllll}\text { Mean frequency: } & \mathbf{0 . 0 1 1} & 0.013 & 0.016 & 0.016\end{array}$

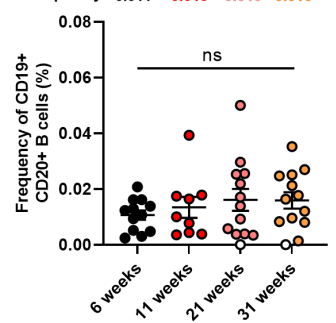

C

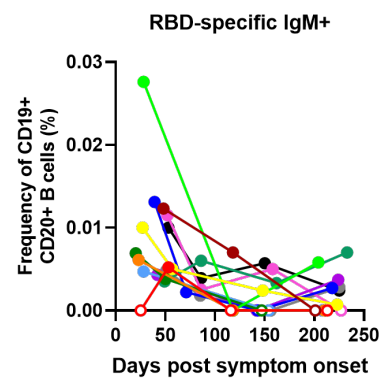

E

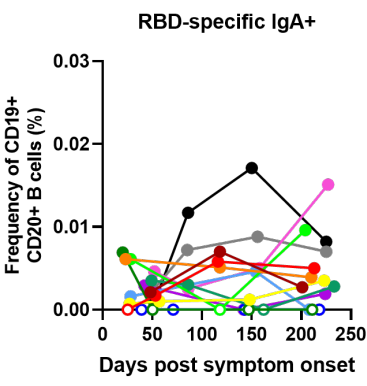

RBD-specific $\lg A+$

Positive donors: $83 \% \quad 78 \% \quad 62 \% \quad 77 \%$ Mean frequency: $0.003 \quad 0.003 \quad 0.004 \quad 0.005$

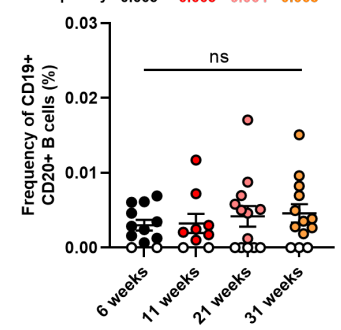

RBD-specific naïve

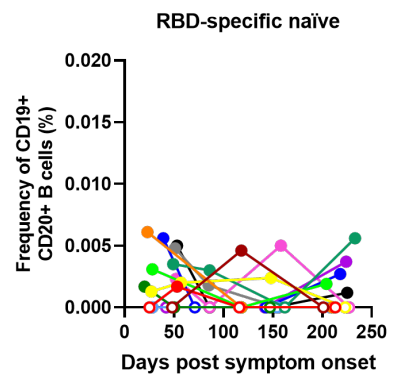

Positive donors: $\mathbf{7 5 \%} \quad \mathbf{4 4 \%} \quad 23 \% \quad 38 \%$ $\begin{array}{llll}\text { Mean frequency: } \mathbf{0 . 0 0 3} & 0.001 & 0.001 & 0.001\end{array}$

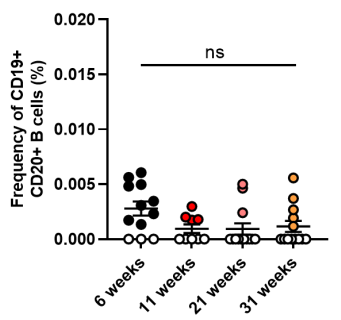

\section{I}

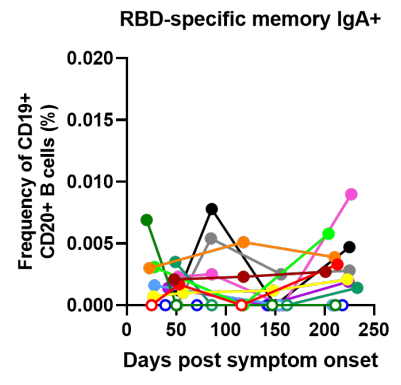

Positive donors: $\mathbf{9 2} \% \quad \mathbf{1 0 0} \% \quad 38 \% \quad 54 \%$ Mean frequency: $0.009 \quad 0.005 \quad 0.002 \quad 0.002$

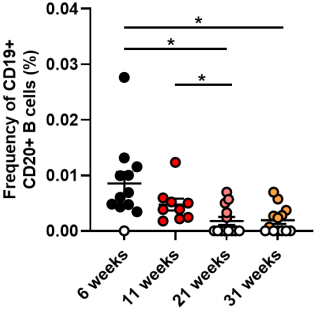

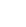




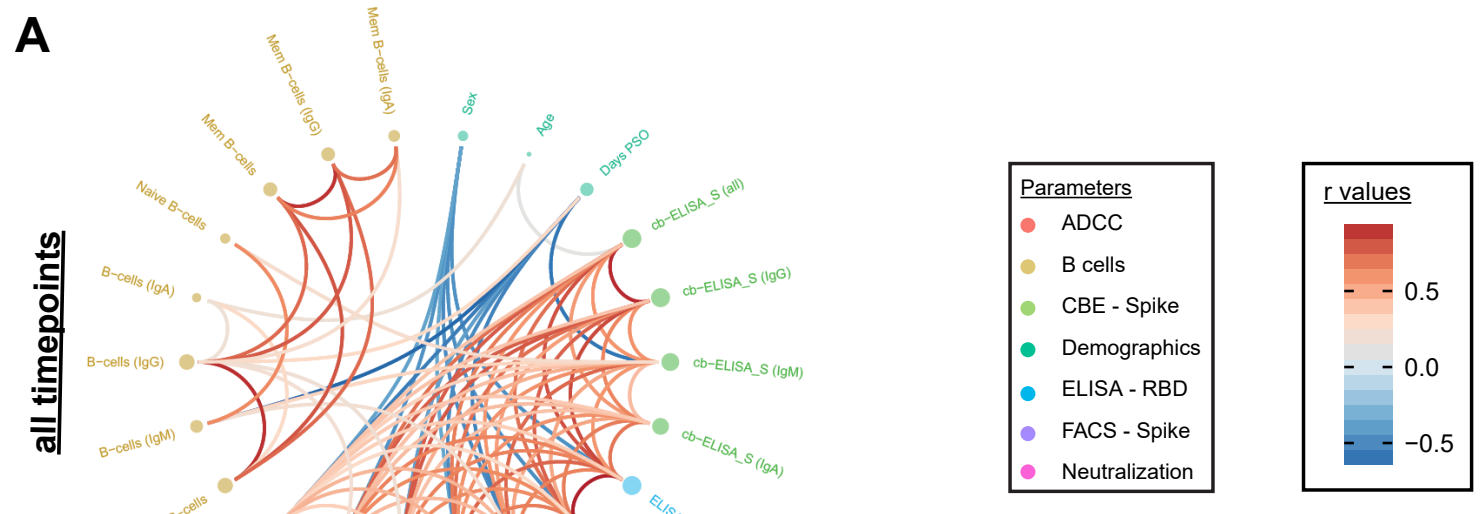

B

D

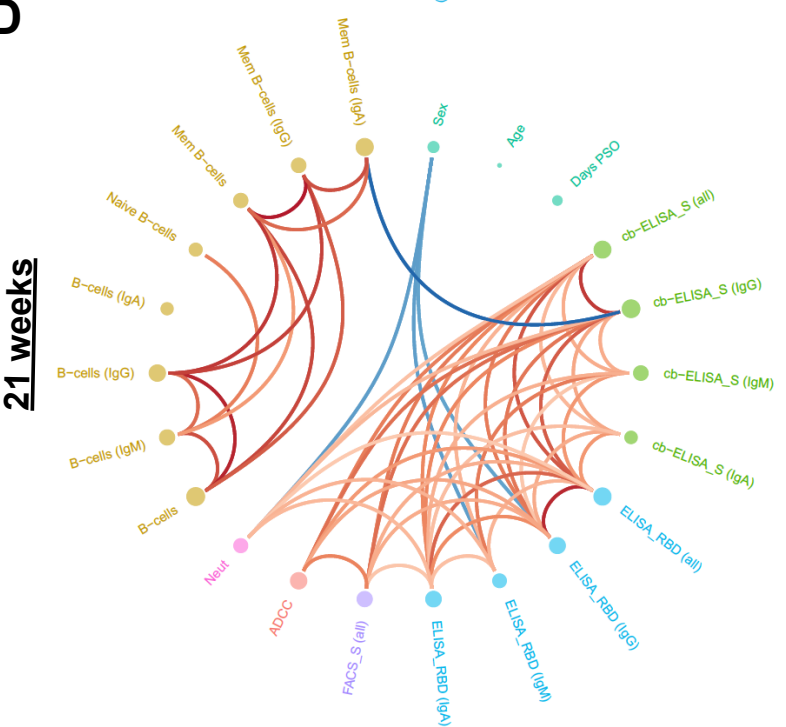

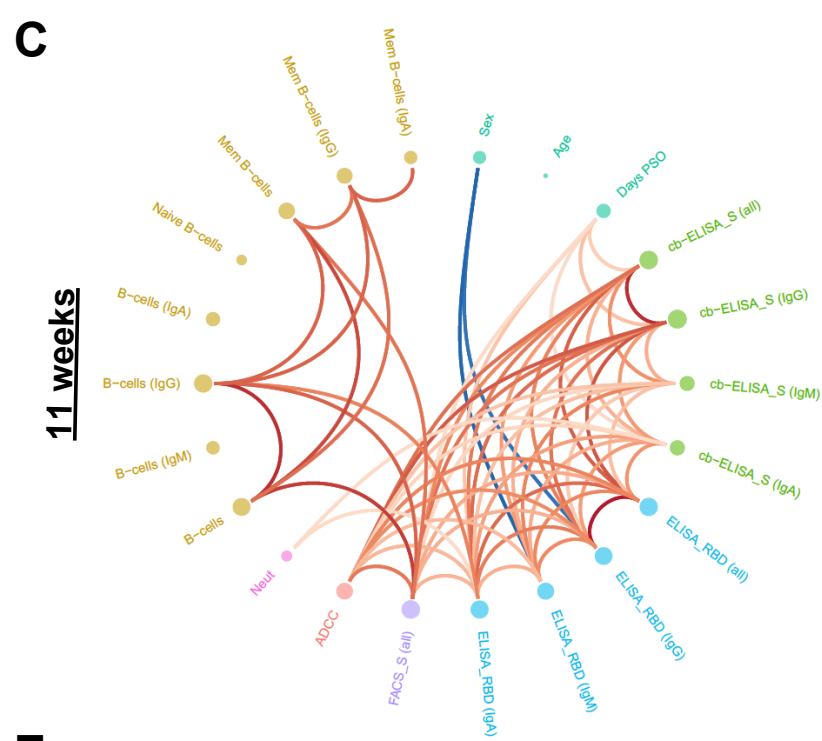

E

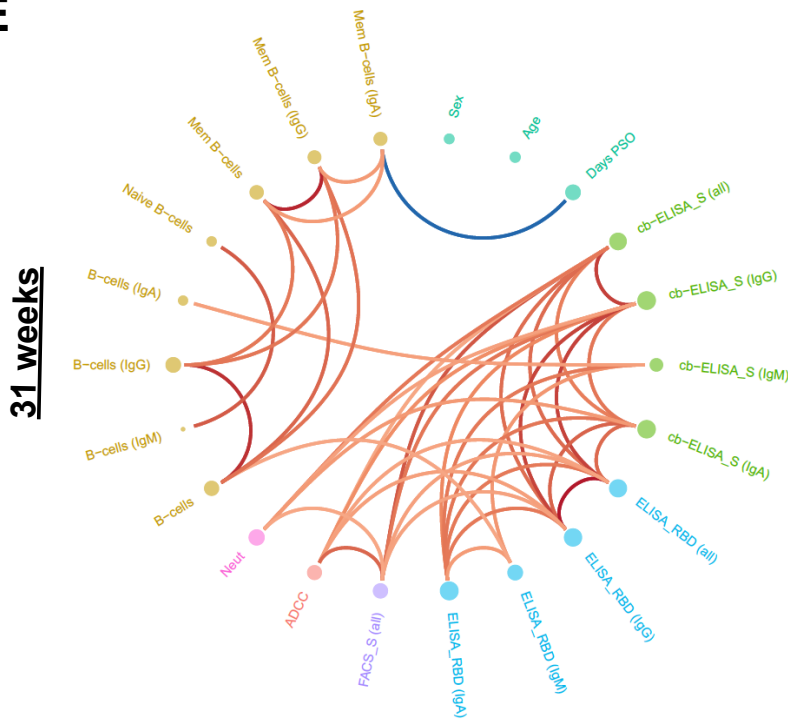

Figure 5. Longitudinal plasticity and separation of B cell and humoral correlation clusters.

Edge bundling correlation plots where red and blue edges represent positive and negative correlations between connected parameters, respectively. Only significant correlations $(p<0.05)$ are displayed. Nodes are color-coded based on the grouping of parameters according to the legend at the bottom. Node size corresponds to the degree of relatedness of correlations. Edge bundling plots are shown for correlation analyses using all data points $(A)$ and datasets of individual time points, i.e., at 6 weeks (B), 11 weeks (C), 21 weeks (D), and 31 weeks (E). 


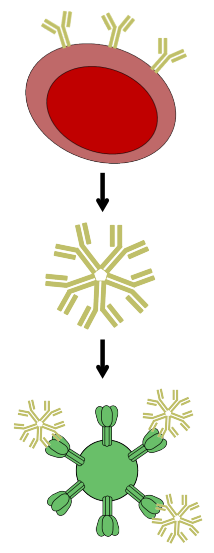

IgG+ B cells
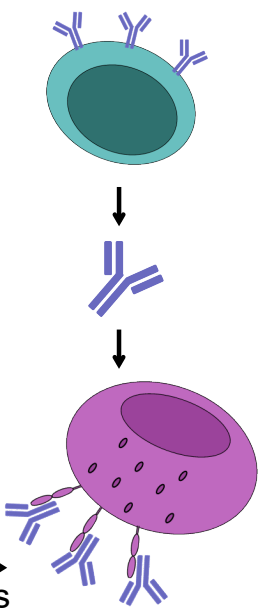

Figure 6. Evolution of humoral immune responses and B cell levels in SARS-CoV-2 convalescent individuals over time.

Area plots showing time series of selected, humoral immune responses and B cell levels by interpolation of normalized, averaged values per parameter and time point. The timeline is shown at the bottom with ticks indicating study time points. 
anti-RBD Abs

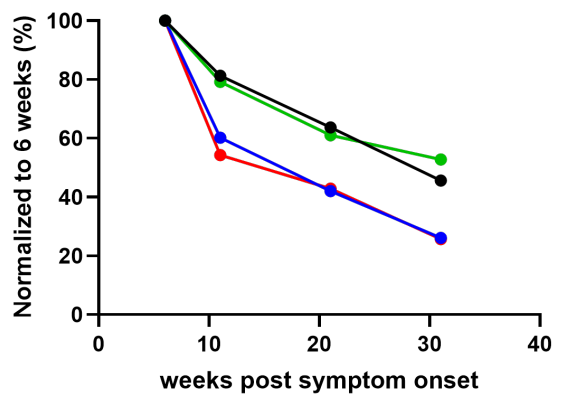

Ab functions

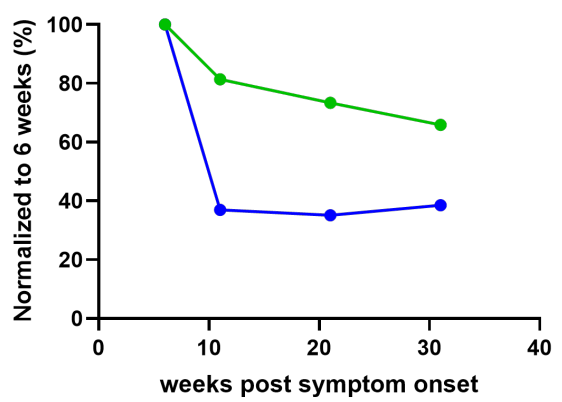

B

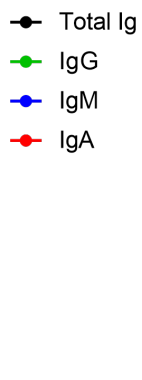

$\rightarrow$ Total Ig

$\rightarrow-\lg G$

$\rightarrow-\lg M$

- IgA $\rightarrow$ ADCC

$\rightarrow$ Neutralization

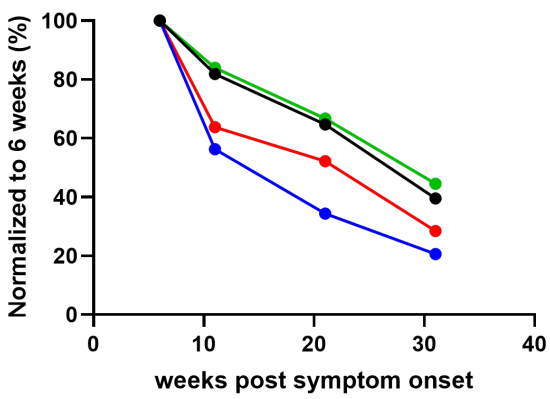

D

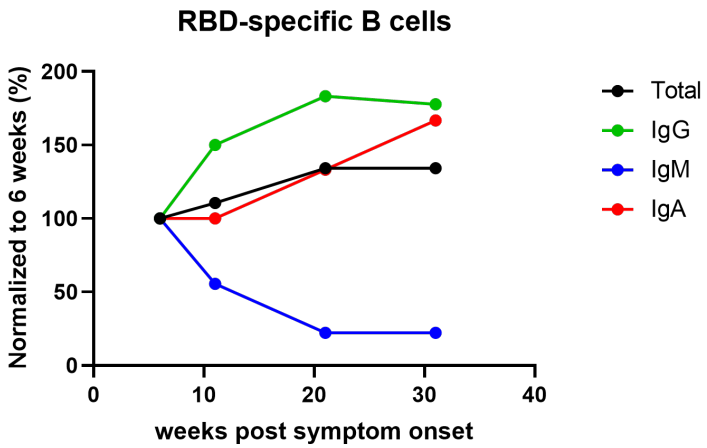

Supplemental Figure 1. Anti-SARS-CoV-2 IgM and IgA levels decline faster than IgG in the convalescence phase.

(A) The graph shown represents the mean values for anti-RBD ELISA (from Figure 1A-D) at different timepoints (6, 11, 21 and 31 weeks) normalized to the 6 weeks timepoint. (B) The graph shown represents the mean values for anti-Spike cell-based ELISA (from Figure 1E-H) at different timepoints $(6,11,21$ and 31 weeks) normalized to the 6 weeks timepoint. (C) The graph shown represents the mean values for neutralization and ADCC responses (from Figure 2) at different timepoints $(6,11,21$ and 31 weeks) normalized to the 6 weeks timepoint. (D) The graph shown represents the mean values for RBD-specific B cell frequencies (from Figure 3B-E) at different timepoints $(6,11,21$ and 31 weeks) normalized to the 6 weeks timepoint. 


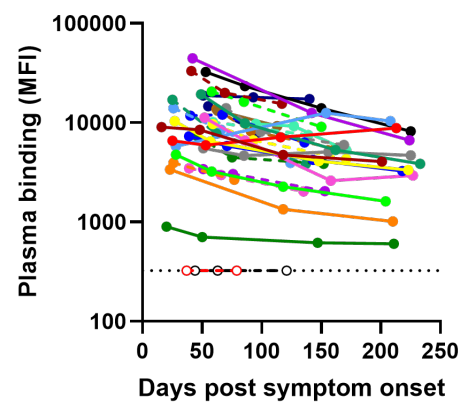

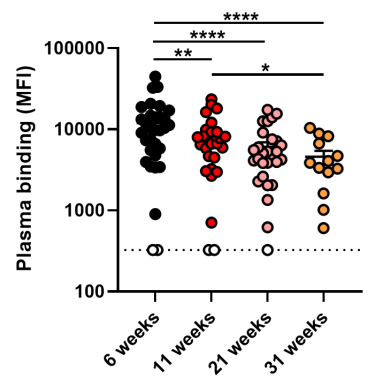

anti-Spike total Ig

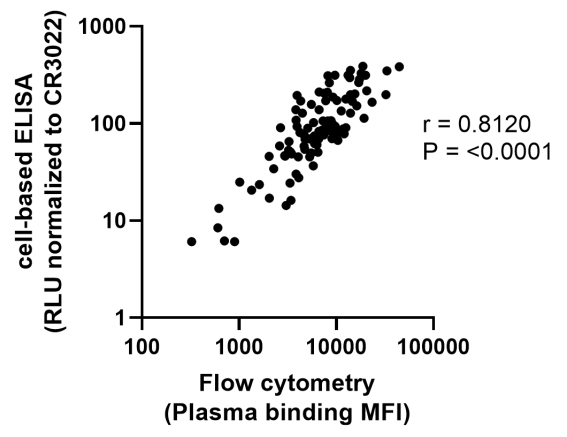

Supplemental Figure 2. Detection of antibodies against SARS-CoV-2 Spike by flow cytometry correlates with anti-Spike detection by cell-based ELISA.

(A) Cell-surface staining of 293T cells stably expressing full-length SARS-CoV-2 Spike using samples from COVID-19+ convalescent donors at different times after symptoms onset $(6,11,21$ and 31 weeks). The graphs shown represent the median fluorescence intensities (MFI) obtained on the GFP+ population. MFIs values obtained with parental 293T (GFP-) were subtracted. (Left panel) Each curve represents the MFIs obtained with the plasma of one donor at every donation as a function of the days after symptom onset. (Right panel) Plasma samples were grouped in different timepoints post-symptom onset $(6,11,21$ and 31 weeks). Undetectable measures are represented as white symbols, and limits of detection are plotted. Error bars indicate means \pm SEM. (B) The levels of anti-Spike total Ig quantified by flow cytometry were correlated with the level of anti-Spike total Ig quantified by cell-based ELISA. Statistical significance was tested using (A) a repeated measures one-way ANOVA with a Holm-Sidak post-test or (B) a Spearman correlation rank test $\left({ }^{*} P<0.05\right.$; ${ }^{*} P<0.01$; $\left.{ }^{* * * *} \mathrm{P}<0.0001\right)$ 
B

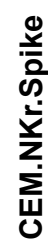

C

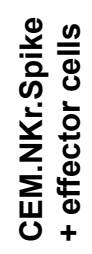

D

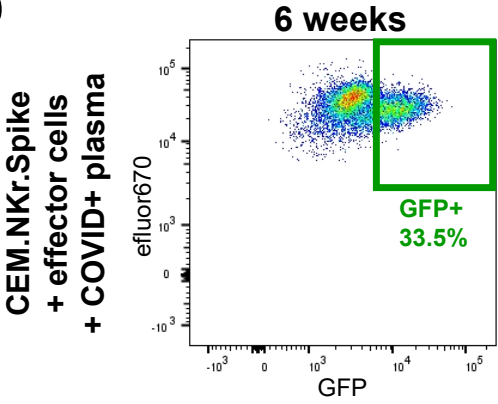

$\%$ ADCC:

$21.7 \%$
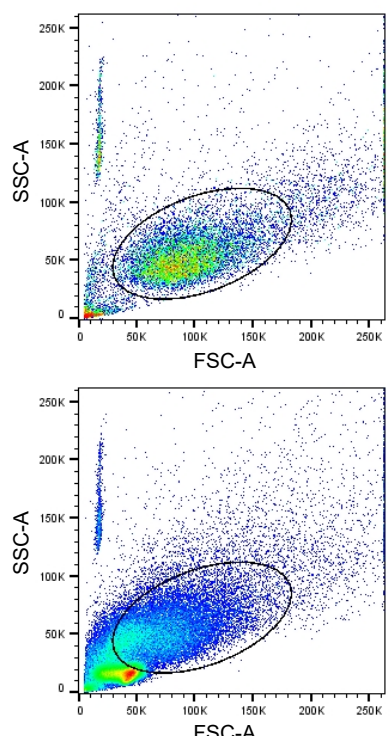
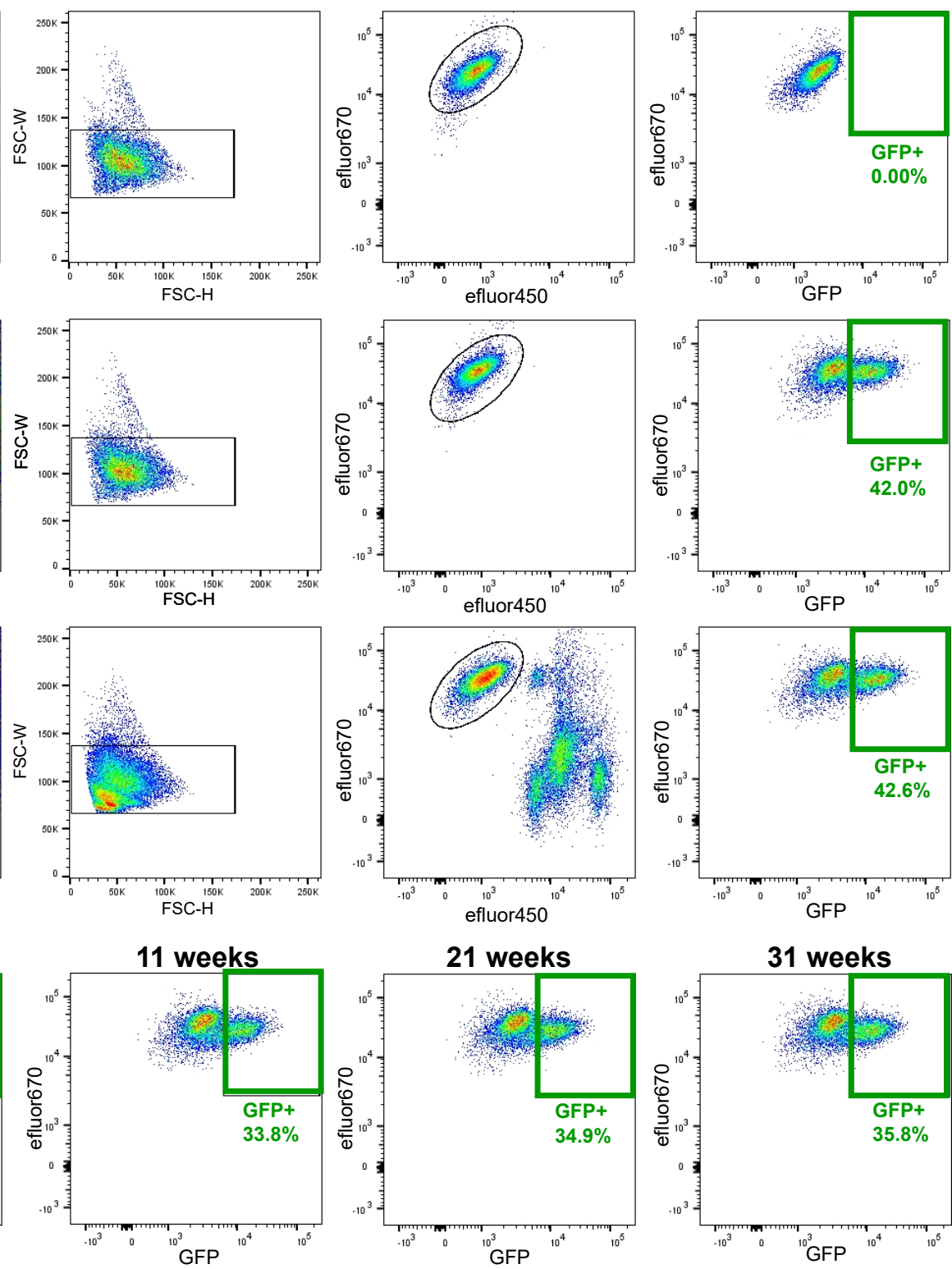

$21.0 \%$

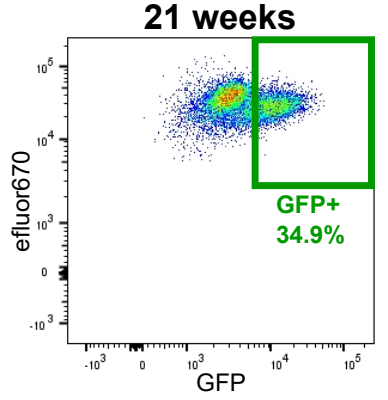

$18.3 \%$
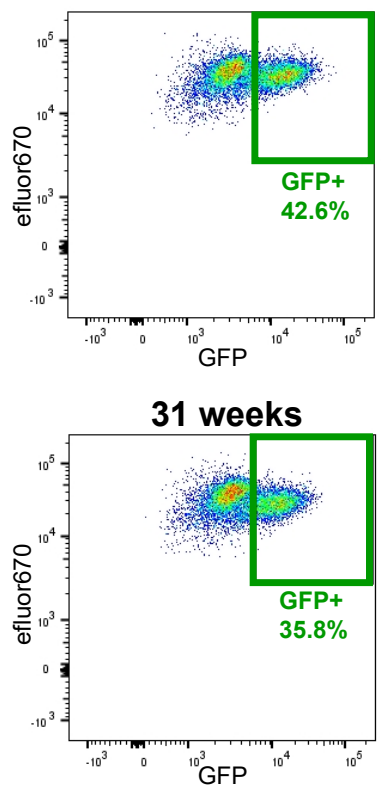

$16.2 \%$

\section{Supplemental Figure 3. Gating strategy for ADCC measurements.}

Target cells were identified according to cell morphology by light-scatter parameters (first column) and excluding doublets cells (second column). Cells were then gated on eFluor670+ cells (excluding the effector cells labeled with eFluor450; third column). Finally, the percentage of GFP+ target cells was used to calculate ADCC activity (last column). Examples of gating using (A) parental CEM.NKr or (B) a 1:1 ratio mix of CEM.NKr and CEM.NKr.Spike as target cells in absence or (C) in presence of effector cells. (D) ADCC assay performed in the presence of plasma samples from one representative convalescent donor at 4 different timepoints post-symptom onset $(6,11,21$ and 31 weeks). 


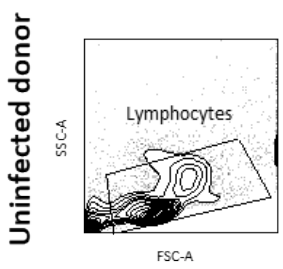

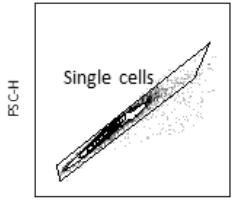

FSC-A

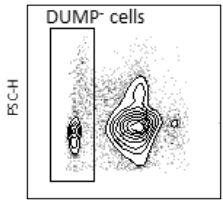

DUMP - BV480

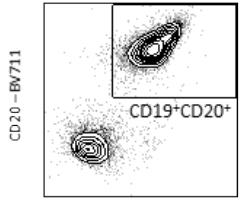

CD19-BV650

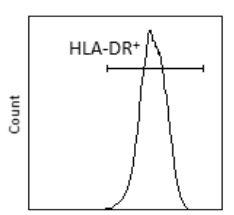

HLA-DR - BB700

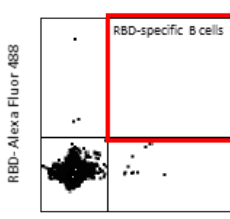

RBD - Alexa Fluor 594

B
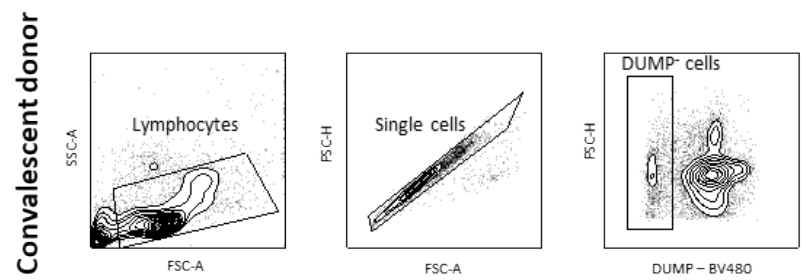

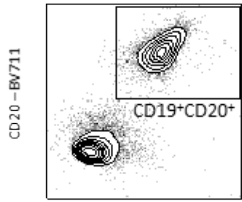

CD19-BV650

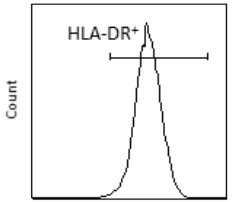

HLA.DR - BB700

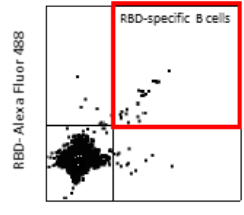

RBD - Alexa Fluor 594

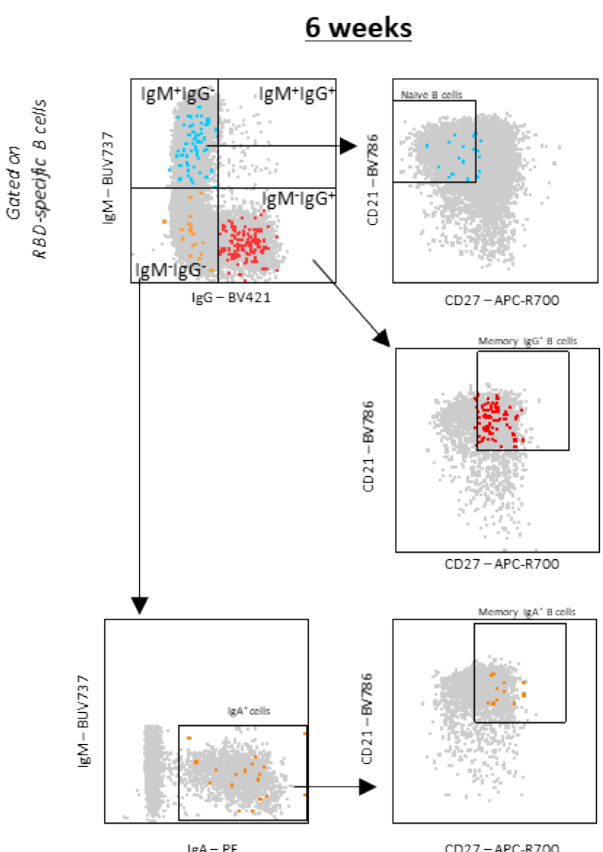

D

$\underline{31 \text { weeks }}$
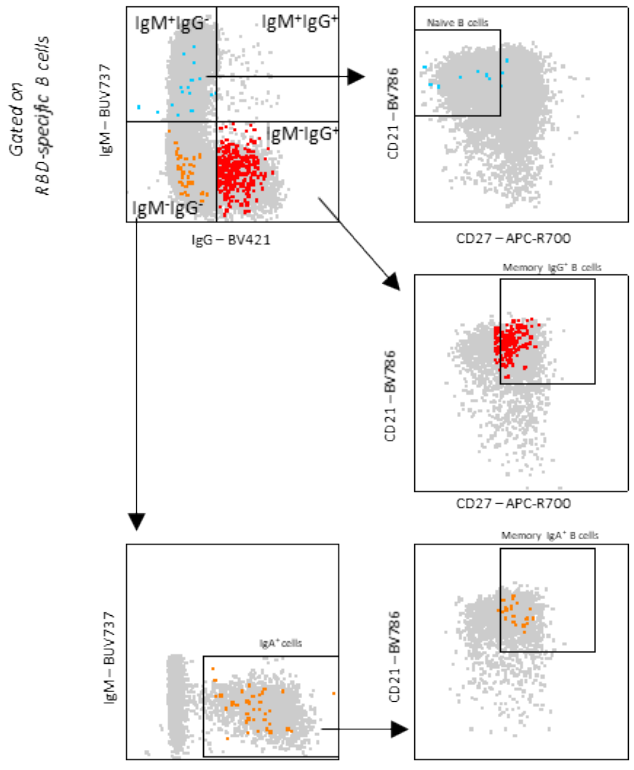

$\operatorname{Ig} A-P E$

CD27-APC-R700

Supplemental Figure 4. Gating strategy for SARS-CoV-2-specific B cell characterization.

(A-B) Representative flow cytometry gates to identify RBD-specific B cells from PBMCs of (A) uninfected and (B) convalescent donor. (C-D) Flow cytometry gates used to differentiate RBD-specific B cell subtypes using isotypic and maturation cell surface markers on samples obtained (C) 6 weeks and (D) 31 weeks post-symptom onset. After identification of isotypic subtypes, RBD-specific naïve and memory B cells were characterized based on surface expression of CD21 and CD27. The different RBD-specific B cell subpopulations were superimposed on total CD19+/CD20+/HLA-DR+ B cells (grey). Legend: IgM+ and naïve IgM+ B cells, blue; IgG+ and memory lgG+ B cells, red; $\lg \mathrm{A}+$ and memory $\lg \mathrm{A}+\mathrm{B}$ cells, orange. 
